\title{
Nieczytelność i nieprzezroczystość. Dwa wymiary wizualności tekstu
}

\begin{abstract}
This work deals with the visuality of the text, in the context of two paths of a reflection on its being: the illegibility/ legibility and transparenty/ opacity. Its aim is to prove, that the text is a visual medium. The first part of the work introduces the main topic by providing a short outline of the history of subject matter, which is typography, the area of visual communication that works with the text. The second part deals with the analysis of the text in terms of aforementioned paths of reflection. The issue of transparenty had to be claryfied first, because firstly it should be proven, that the text is not invisible for an eye. From this matter the work passes to the notion of illegibility: if the text is not transparentvisually neutral - but instead, highly graphically characterised, then the question is, if it does remain readable.
\end{abstract}

Keywords: typography, visual communication, text, visuality, illegibility, transparency

\section{Wstęp}

$\mathrm{T}$

ermin „typografia” odnosi się do dziedziny projektowania graficznego oraz projektowania komunikacji. Obejmuje on wszystkie aspekty istnienia tekstu: od kształtu pojedynczej litery po aranżację całego bloku tekstu na stronie. Z oczywistych względów, gdy pomyśleć o wizualnych formach mediów, na myśl przychodzi nie tekst, a telewizja czy reklama. Tekst jednak, jak każde inne medium, również wymaga zaprojektowania. Projektant musi dokonać szeregu decyzji co do formy tekstu, zanim zostanie on opublikowany. Decyzje te nie mają podłoża czysto estetycznego - są podpierane funkcjonalnością tekstu. Ta funkcjonalność 
często przesłania możliwości graficznego eksperymentowania z tekstem z obawy o utratę czytelności. Jako że tekst jest nośnikiem treści, co stanowi jego główną funkcję, przeoczeniu ulega jego wizualność, która może wnosić dodatkowe wartości do odbioru jego treści. Forma wizualna tekstu jest bowiem kontekstem dla jego treści - może wzmacniać przekaz lub go zakłócać. Celem niniejszego artykułu jest więc ukazanie tekstu jako formy wizualnej, najpierw poprzez krótkie przedstawienie historii dziedziny zajmującej się projektowaniem rozwiązań tekstowych, czyli typografii, a następnie przez poddanie tekstu analizie na dwóch wyróżnionych osiach refleksji - nieczytelności i przezroczystości. Nieczytelności, ponieważ poprzez ingerowanie w formę tekstu istnieje prawdopodobieństwo utraty możliwości przekazania jego treści, czyli podstawowej funkcji wszelkiego rodzaju tekstów. Problem przezroczystości tekstu traktuje natomiast o neutralności jego formy wizualnej - a tym samym jego zdolności wpływania na przekaz, jaki niesie - oraz o problemie, czy tekst fizycznie istnieje jako medium wizualne, czy też jest niewidoczny dla odbiorcy. Nieprzeźroczysty tekst w tym znaczeniu byłby widoczny jako medium wizualne samo w sobie, wzrok by się na nim „zatrzymywał”, a nie przez niego „przechodził”. Innymi słowy, byłby komunikatem autorefleksyjnym, skupiającym na sobie uwagę odbiorcy, zamiast kierować ją na przekaz ${ }^{1}$ Kwestia przezroczystości musiała zostać rozważona jako pierwsza, ponieważ najpierw należy udowodnić, że tekst nie jest niewidoczny dla oka, nie jest czymś neutralnym w swojej materialności. Z tego pojęcia artykuł przechodzi do kwestii nieczytelności - jeśli tekst nie jest przezroczysty, neutralny wizualnie, lecz przeciwnie, mocno nacechowany graficznie, to czy pozostaje on czytelny i nadal pełni swoją rolę?

\section{Najpierw rzeczy pierwsze ${ }^{2}$ - typografia w XX wieku}

\subsection{Wyjście z drukarni}

Wiek XX to dla typografii okres gwałtownych zmian, kiedy to pod wpływem burzliwych przemian w sztuce do głosu dochodziły odmienne koncepcje na temat tego, czym ma być typografia. Do tej pory typografia miała ograniczone pole rozwoju, zamknięta w przestrzeni czterech ścian drukarni; była wręcz jej synonimem $^{3}$. Wraz z rozpoczęciem nowego stulecia, dzięki zainteresowaniu artystów,

\footnotetext{
${ }^{1}$ Por. U. Eco, Komunikat estetyczny, w: idem, Nieobecna struktura, tłum. A. Weinsberg, P. Bravo, Wydawnictwo KR, Warszawa 1996.

2 Tytuł rozdziału jest nawiązaniem do tytułu manifestu projektantów-grafików, autorstwa Kena Garlanda Najpierw rzeczy pierwsze z 1964 roku (i jego uaktualnionej wersji z 1999 roku, Najpierw rzeczy pierwsze 2000).

3 Definicja hasła „typografia”: „historyczna nazwa drukarni”. Za: M. Hurkacz, Typografia, 15 listopada 2009 r., https://liternictwo.asp.krakow.pl/?p=449 [dostęp: 28.12.2019].
} 

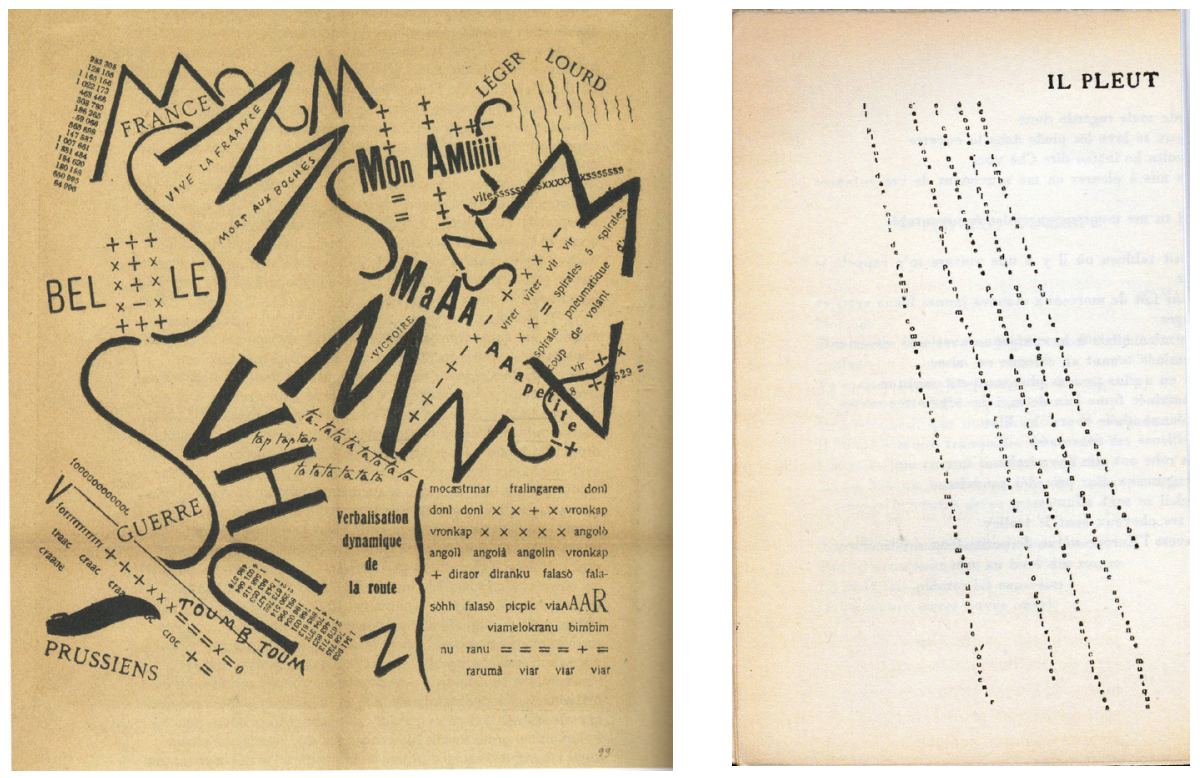

Fot. 1-2. Filippo Tommaso Marinetti, wiersz Apres la Marne, Joffre visita le front en auto, 1915 rok; Guillaume Apollinare, wiersz Il Pleut (Pada deszcz) z książki Calligrammes, wydawnictwo Mermod, 1917 rok

Źródło: fot. 1, Triumf typografii. Kultura, komunikacja, nowe media, red. H. Hoeks, E. Lentjes, tłum. M. Komorowska, d2d.pl, Kraków 2017, s. 158; fot. 2, J. Mrowczyk, Z. Kolesár, Historia projektowania graficznego, tłum. J. Goszczyńska, Karakter, Kraków 2018, s. 131.

staje się czymś więcej niż tylko rzemiosłem - po raz pierwszy twórcy z obszaru sztuk klasycznych na swój warsztat biorą litery, znaki interpunkcyjne oraz cyfry, niejako przywracając pismu jego pierwotną naturę sprzed momentu fonetyzacji, gdy miało jeszcze wciąż formę przedstawieniową ${ }^{4}$. Pismo ponownie staje się obrazem. Pierwsze rewolucyjne zmiany w świecie znaków alfabetycznych przypisać można futurystom. Założyciel tego kierunku, Filippo Tommaso Marinetti, burzył nie tylko formę obrazu malarskiego, ale i strukturę tekstu. Marinetti „znosił harmonię zadrukowanej strony”, by móc oddać tak gloryfikowane przez siebie dynamikę i pęd. Najpełniej wyrażała tę ideę stworzona przez niego forma poezji, „słowa na wolności”6 (parole in libertà):

${ }^{4}$ J. Mrowczyk, Z. Kolesár, Historia projektowania graficznego, tłum. J. Goszczyńska, Karakter, Kraków 2018, s. 129. Co ciekawe, okładka polskiego wydania nawiązuje swoim projektem do nieczytelności tekstu.

${ }^{5}$ Ibidem, s. 110.

${ }^{6}$ Ibidem, s. 132. 
[...] której dynamikę podkreślały rewolucyjny język (pozbawiony przymiotników, przysłówków i interpunkcji) oraz ekspresywna typografia. Zlikwidowała ona całkowicie linearne uporządkowanie tekstu. Właściwości dźwiękowe mowy, od krzyku aż po szept, odwzorowała poprzez rodzaj, wielkość i grubość pisma? .

Podobne w swoich zabiegach typograficznych wiersze tworzył poeta Guillaume Apollinaire. Nazywał je kaligrafami i były to formy poezji wizualnej, w której autor rezygnował z linearności tekstu. W 1916 roku został opublikowany jego wiersz Il Pleut (Pada deszcz), gdzie poszczególne litery tak są rozmieszczone na stronie, że imitują spadające krople deszczu ${ }^{8}$. Apollinaire wprost w jednym ze swoich tomów nazywa siebie „malarzem”.

Następna grupa artystów bierze tekst na swój warsztat. W atmosferze napięcia i chaosu wywołanego I wojną światową dadaiści negują wszelkie normy społeczne i kulturowe oraz odzierają sztukę z jej zasad i praw ${ }^{10}$. Hanowerski artysta Kurt Schwitters, którego sztuka jest bardzo zbliżona do założeń dadaistycznej antysztuki, choć on sam tak jej nie nazywałł" ${ }^{11}$ zakłada czasopismo „Merz” (1923). Tytuł magazynu artysta rozumie jako „zebranie razem dla celów artystycznych wszystkich materiałów, jakie tylko dadzą się pomyśleć, a pod względem technicznym - zasadę równowartości każdego z materiałów [...]"12. W myśl tej zasady tworzył nie tylko swoje obrazy malarskie czy monumentalne konstrukcje rzeźbiarskie, ale i właśnie oprawę magazynu „Merz”. Słowo staje się tam równie uprawnionym tworzywem wizualnym jak obraz.

\subsection{Skonstruowanie siatki}

Nowa rola tekstu spotyka się jednak z krytyką. Tekst w ten sposób eksploatowany traci niekiedy swoją czytelność. W obronie głównej funkcji tekstu oraz w opozycji do działań futurystów i dadaistów powstają nurty proklamujące „typograficzną klarowność, przejrzystość i funkcjonalność”13. W latach 30. za działaniem projektantów stoi przekonanie, że czytelny przekaz poprawi stosunki społeczne i zapobiegnie ponownej tragedii ${ }^{14}$. W działającej wówczas, mającej duże znaczenie

${ }^{7}$ Ibidem.

${ }^{8}$ Wprowadzenie do współczesnej typografii, „2+3D”, 28 grudnia 2009, http://www.2plus3d. pl/artykuly/wprowadzenie-do-wspolczesnej-typografii [dostęp: 1.01.2020].

9 J. Mrowczyk, Z. Kolesár, Historia projektowania..., s. 131. W 1914 roku wydaje kilka utworów w tomie Et moi aussi je suispeintre, co znaczy „I ja też jestem malarzem”.

${ }_{10}$ Słownik terminologiczny sztuk pięknych, red. K. Kubalska-Sulkiewicz, Wydawnictwo Naukowe PWN, Warszawa 2012, s. 82.

${ }^{11}$ A. Kłos, MERZ - Kurta Schwittersa połqczenie sztuki z życiem, 20 maja 2016, https:// retroavangarda.com/merz-kurt-schwitters/ [dostęp: 1.01.2020].

12 Ibidem.

13 Wprowadzenie do współczesnej typografii, 2+3D.

${ }^{14}$ Mowa o I wojnie światowej. Zob. J. Mrowczyk, Z. Kolesár, Historia projektowania..., s. 138. 

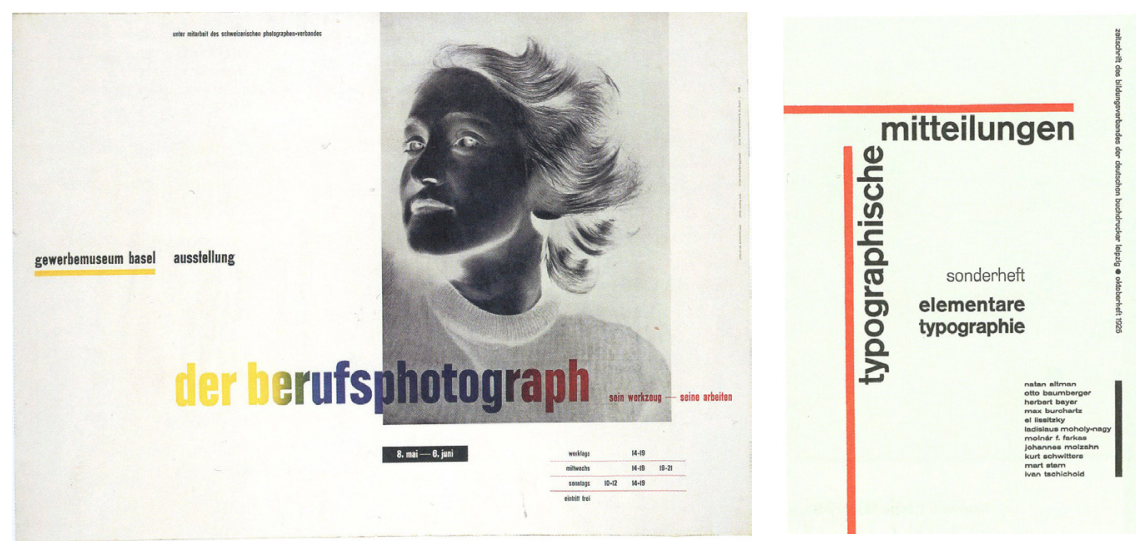

Fot. 3-4. Jan Tschichold, plakat Der Breufsphotograph (Profesjonalny fotograf), 1938 rok oraz Jan Tschichold, okładka elementare typographie, 1925 rok

Źródło: fot. 3, J. Mrowczyk i Z. Kolesár, Historia projektowania..., s. 155; fot. 4, Triumf typografii..., red. H. Hoeks, E. Lentjes, s. 116.

dla historii projektowania, szkole Bauhaus, nauczał węgierski projektant László Moholy-Nagy. To on wprowadził zasady funkcjonalizmu ${ }^{15} \mathrm{~W}$ mury szkoły, wpisując się w rodzące się wówczas pretensje do racjonalizacji działań typograficznych, by tekst przede wszystkim przekazywał komunikat. Napisał artykuł pt. Nowa typografia (Die Neue Typographie, 1923), będący „zbiorem podstawowych zasad nowej modernistycznej typografii”16. Projektant stawia aspekt czytelności tekstu nad jakąkolwiek jego estetyką, ponieważ „typografia jest narzędziem komunikowania”"17, jej istotą i fundamentalną funkcją jest przekazywanie treści. Autorem podobnej w swoim wydźwięku publikacji jest Jan Tschichold. Nowa typografia. Podręcznik dla tworzq̨cych w duchu współczesności (1928) to kompendium wiedzy na temat rozwijającego się wówczas kierunku nowej typografii, który przyjmował „racjonalne zasady tworzenia”" ${ }^{18}$ w swoich projektach. Tschichold przyrównuje projektowanie typograficzne jednocześnie do malarstwa i architektury: z architekturą

15 „Kierunek we współczesnej architekturze, urbanistyce i sztuce użytkowej, którego głównym założeniem jest uznanie nadrzędności i funkcji użytkowej przedmiotu”. Cyt. za: Słownik języka polskiego PWN, https://sjp.pwn.pl/sjp/funkcjonalizm;2460387.html [dostęp: 1.01.2020], hasło: funkcjonalizm.

${ }^{16}$ Widzieć/ Wiedzieć. Wybór najważniejszych tekstów o dizajnie, red. P. Dędowski, J. Mrowczyk, Karakter, Kraków 2015, s. 15.

${ }^{17}$ Ibidem.

${ }^{18}$ Nowa typografia. Podręcznik dla tworzq̨cych w duchu współczesności, „2+3D”, 4 września 2011, http://www.2plus3d.pl/artykuly/nowa-typografia-podrecznik-dla-tworzacych-w-duchuwspolczesnosci [dostęp: 1.01.2020]. 
łączy je potrzeba rozwiązania funkcjonalnego problemu (stąd roszczenia o racjonalne narzędzia), a z malarstwem problem estetyczny (typografia, jak podkreśla, jest ze swej natury zjawiskiem wizualnym) ${ }^{19}$.

Styl szwajcarski powstał w latach 30. XX wieku, gdy nurt nowej typografii dotarł do Szwajcarii. Nowy styl to efekt połączenia wszystkich wcześniejszych dokonań na polu typografii (od dadaistów po nurt funkcjonalny), ze słynną szwajcarską precyzyjnością ${ }^{20}$. To tu najpełniej mogły zostać wyegzekwowane postulaty racjonalnej typografii oraz zapewnione wystarczająco precyzyjne narzędzia: prostota, oparcie projektu o grid (siatka), typofoto (obecność czarno-białej fotografii w tekście lepiej przekaże treść niż ilustracja) oraz elementy geometryczne (jedyna forma ilustracji ${ }^{21}$. Celem projektantów było „nadanie tekstowi i obrazowi struktury, tworząc logiczną i dobrze zorganizowaną całośc”22.

\subsection{Oderwanie od Starego Świata}

Z powodu wybuchu II wojny światowej projektowanie w Europie zamiera na pewien czas, Bauhaus zostaje zamknięty, a jego wykładowcy wyjeżdżają do Stanów Zjednoczonych i Szwajcarii. Neutralna Szwajcaria jako kraj o dobrych warunkach ekonomicznych i wysokim poziomie edukacji, udoskonala surowe zasady stylu szwajcarskiego, wedle których typografia miała służyć, jako instrument do poprawiania stosunków społecznych ${ }^{23}$. Stany Zjednoczone natomiast przeistaczają go w styl międzynarodowy, nadając mu nową, bardziej praktyczną funkcję, by mógł przysłużyć się reklamie będącej wówczas w momencie rozwoju ${ }^{24}$. Prym wiedzie więc styl szwajcarski w tych dwóch postaciach - klasycznej i skomercjalizowanej. Okres stagnacji nie trwa jednak długo, sprzeciw wobec surowości stylu modernistycznego - znajdującego swoje zastosowanie już jedynie w amerykańskich korporacjach $^{25}$ - wybucha w czasach rewolucji obyczajowej lat 60.: „postulaty społecznej i politycznej wolności [...]”26, inspiracje muzyką, narkotykami (LSD i doświad-

19 J. Tschichold, Nowe życie druku, w: Widzieć/ Wiedzieć..., red. P. Dędowski, J. Mrowczyk, SS. 28-29.

${ }^{20}$ Ch. Gassner, Nowa typografia. Od secesji do końca druku wypukłego, w: Triumf typografii. Kultura, komunikacja, nowe media, red. H. Hoeks, E. Lentjes, tłum. M. Komorowska, d2d.pl, Kraków 2017, s. 117.

21 A. Turbicka, Szkoła szwajcarska (Swiss Style) i jej wykorzystanie w projektowaniu stron internetowych, 28 kwietnia 2016, https:/grafmag.pl/artykuly/szkola-szwajcarska-swiss-style-ijej-wykorzystanie-w-projektowaniu-stron [dostęp: 1.01.2020].

22 C. Gassner, Nowa typografia...

23 J. Mrowczyk, Z. Kolesár, Historia projektowania..., ss. 220 i 226.

24 Ibidem, ss. 227-228.

25 R. Poynor, Typografia postmodernistyczna. Przerabianie alfabetu, demontaż strony, w: Triumf typografii..., red. H. Hoeks, E. Lentjes, s. 125.

${ }^{26}$ Wprowadzenie do współczesnej typografii, „2+3D”. 

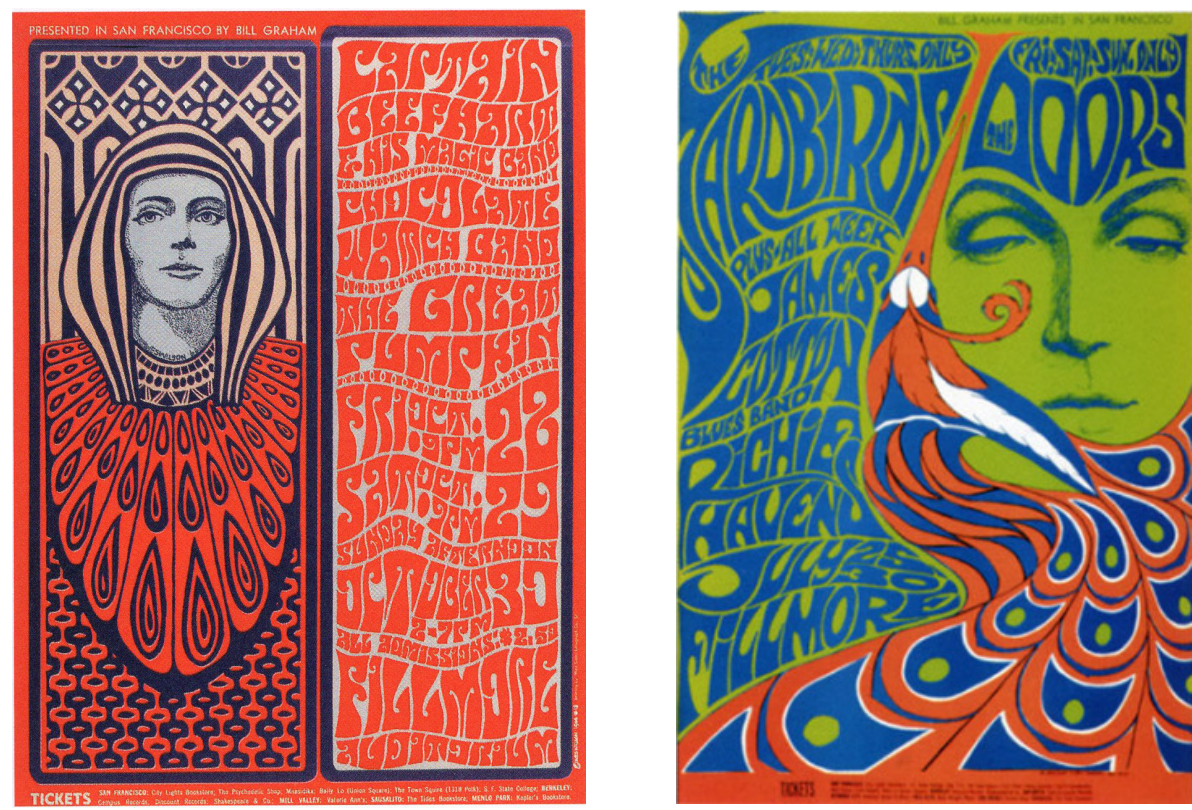

Fot. 5-6. Wes Wilson, plakat reklamowy koncertów w Fillmore Auditorium, San Francisco, 1966 rok; Bonnie Maclean, plakat psychodeliczny, 1967 rok

Źródło: fot. 5, J. Mrowczyk, Z. Kolesár, Historia projektowania..., s. 269; fot. 6, A. Kłos, Styl psychodeliczny w projektowaniu graficznym, 20 kwietnia 2016, https://retroavangarda.com/ styl-psychodeliczny-w-projektowaniu-graficznym/ [dostęp: 1.01.2020].

czanie „nowych światów”27) oraz kulturą Wschodu (buddyzm) doprowadziły do powstania zupełnie nowych jakości. Do bardziej rozpoznawalnych twórców tego okresu należał Wes Wilson, twórca plakatu psychodelicznego, w którym „obraz rozpływa się, faluje w rytm muzyki, a wraz z nim napisy, stanowiące integralną część obrazu”28. Inspiracją dla Wilsona była sztuka secesyjna i wizje narkotyczne.

Innym elementem przemian było zatarcie się granicy między sztuką czystą a użytkową: młodsze pokolenia traktowały plakaty jak klasyczne obrazy, a okładki płyt jako nowe pole ekspresji ${ }^{29}$. W latach 70. XX wieku w Wielkiej Brytanii rodzi się punk, ruch undergroundowy, sprzeciwiający się materializmowi i władzy ${ }^{30}$. Młode pokolenie daje temu wyraz w muzyce, ubiorze oraz w każdej formie przed-

${ }^{27}$ J. Mrowczyk, Z. Kolesár, Historia projektowania..., ss. 268-269.

${ }^{28}$ A. Kłos, Styl psychodeliczny w projektowaniu graficznym, 20 kwietnia 2016, https:// retroavangarda.com/styl-psychodeliczny-w-projektowaniu-graficznym/ [dostęp: 1.01.2020].

29 J. Mrowczyk, Z. Kolesár, Historia projektowania..., s. 268.

${ }^{30}$ Wprowadzenie do współczesnej typografii, „2+3D”. 

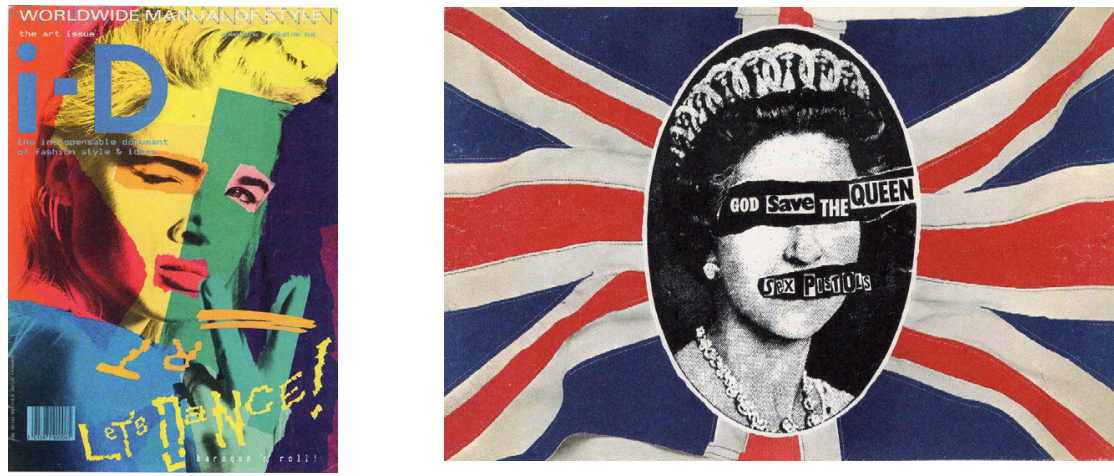

Fot. 7-8. Terry Jones, okładka czasopisma „I-D”, nr 28, 1985 rok i Jamie Reid, plakat towarzyszący wydaniu płyty God Save the Queen, zespół Sex Pistols, 1977 rok Źródło: fot. 7, J. Mrowczyk, Z. Kolesár, Historia projektowania..., s. 281; fot. 8, J. Mrowczyk, Z. Kolesár, Historia projektowania..., s. 280.

stawienia graficznego (plakaty, czasopisma i okładki płyt). Powstaje projektowanie subkulturowe, będące drugim, nieoficjalnym kierunkiem wobec głównego nur$\mathrm{tu}^{31}$. Typografia punkowa rezygnuje z zasad na rzecz swobodnego projektowania w duchu praktyk D.I.Y. (Do It Yourself). Pierwsze punkowe prace tworzone były amatorsko - obrazy, litery, słowa wycinano i sklejano w dynamiczne kolaże lub pisano ręcznie - dopiero z czasem sprofesjonalizowano ten kierunek, a zawodowi projektanci zaadaptowali metody typografii punkowej2 ${ }^{32}$. Między innymi Terry Jones, były dyrektor artystyczny brytyjskiego „Vogue”, nowe techniki undergroundowej typografii wykorzystał w magazynie ${ }^{33}$.

\subsection{Poszatkowanie „gridu”}

Projektanci-graficy pragnęli oddać wieloaspektowość życia oraz jego kulturowe zróżnicowanie, stąd potrzeba oderwania się od funkcjonalnego stylu szwajcarskiego $^{34}$. Głównym orędownikiem nowego nurtu, sprzeciwiającego się skostniałemu stylowi szwajcarskiemu, był Wolfgang Weingart, inicjator nurtu nazywanego nową falą czy szwajcarskim punkiem. Szwajcarska typografia opierała swoje istnienie na wynalazku siatki ( $g r i d)$, tak by elementy znajdujące się na stronie tworzyły przejrzysty układ, a tym samym czytelny tekst - według Weingarta nie istnieje

\footnotetext{
${ }^{31}$ R. Poynor, Typografia postmodernistyczna...

32 J. Mrowczyk, Z. Kolesár, Historia projektowania..., ss. 280-281.

33 Ibidem, s. 281.

${ }^{34}$ R. Poynor, Typografia postmodernistyczna...
} 

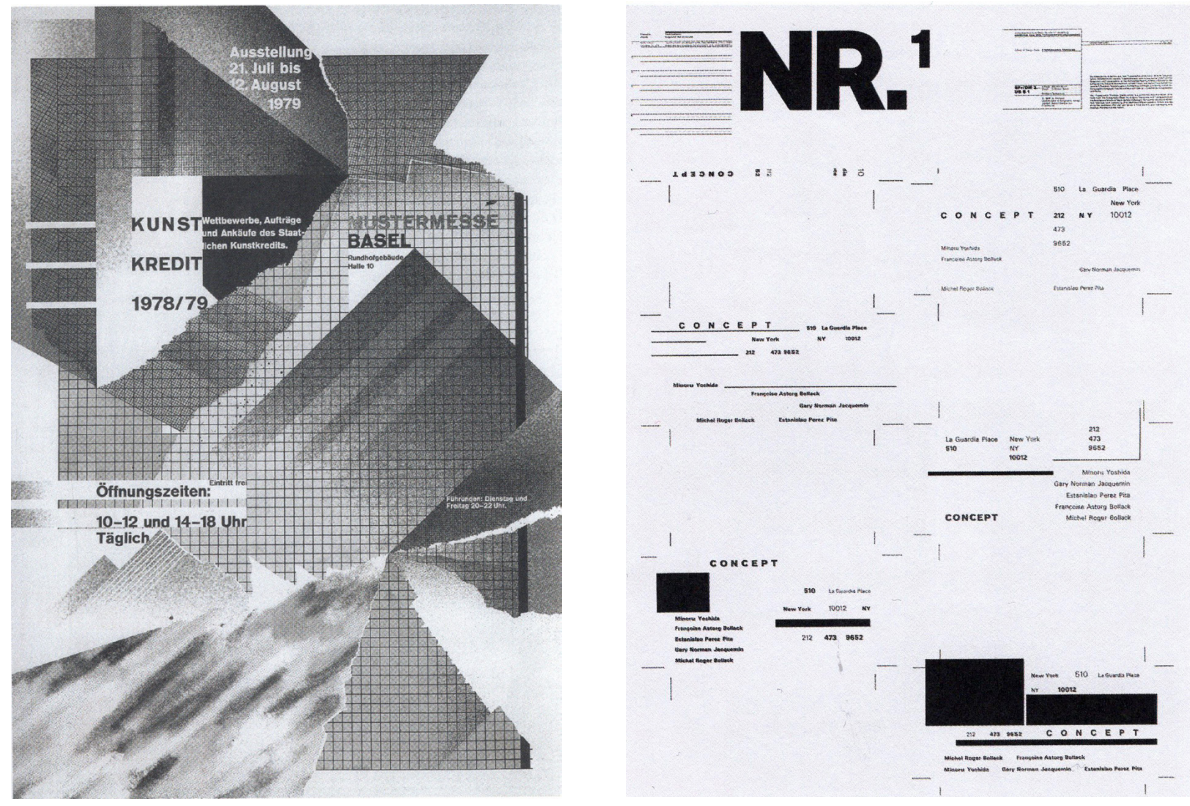

Fot. 9-10. Wolfgang Weingart, plakat wystawy artystycznej w Bazylei, 1979 rok; pierwszy z serii plakatów Typographic Process (Proces typograficzny), Organised Text Strustures (Uporządkowanie struktury tekstu), 1974 rok

Źródło: fot. 9, J. Mrowczyk, Z. Kolesár, Historia projektowania..., s. 277; fot. 10, J. Mrowczyk, Z. Kolesár, Historia projektowania..., s. 276.

tylko jedna metoda pozwalająca osiągnąć taki efekt ${ }^{35}$. Mówił wręcz, że „istnieje nie tylko jeden rodzaj szwajcarskiej typografii”36. Swoim pracom nadawał malarskie walory, jednocześnie nie rezygnując z ich czytelności ${ }^{37}$.

Zagadnienie czytelności było też podejmowane przez Cranbrook Academy of Art, gdzie w latach 1971-1995 amerykańską akademią kierowała Katherine McCoy. Jest ona współautorką eseju Typografia jako dyskurs (1988), w którym pochylając się nad problemem czytelności, stawia tezę o nowym rodzaju doświadczenia, w ramach którego czytanie i oglądanie przenikają się nawzajem ${ }^{38}$. W Cranbrook Academy uczeni starają się nadać nowym, dynamicznie wielowątkowym dzia-

${ }^{35}$ Typograficzny pejzaż Wolfganga Weingarta, „2+3D”, 5 marca 2010, https://www.2plus3d. pl/artykuly/typograficzny-pejzaz-wolfganga-weingarta [dostęp: 1.01.2020].

${ }^{36}$ W. Weingart, How can one make Swiss typography, w: Looking Closer 3: Classic Writings on Graphic Design, red. M. Bierut, Allworth Press, New York 1999, s. 219, cyt. za: Typograficzny pejzaż Wolfganga Weingarta, 2+3D.

37 Typograficzny pejzaż Wolfganga Weingarta, 2+3D.

${ }^{38}$ Wprowadzenie do współczesnej typografii, 2+3D. 
łaniom w typografii uzasadnienie teoretyczne, chcąc je uporządkować ${ }^{39}$. Jedną z pierwszych prac, w której studenci Akademii posłużyli się teorią, było opracowanie wizualne jednego z numerów magazynu „The Visible Language” z 1978 roku. Forma wizualna numeru była zdeterminowana przez treść, jaką niósł tekst ${ }^{40}$. W 1990 roku małżeństwo McCoy pisze pracę podsumowującą dokonania w Cranbrook Academy pt. Cranbrook Design: The New Discourse. Tłumaczą w niej rolę tych eksperymentów graficznych: pozwalają one mianowicie uświadomić sobie relacje łączące tekst z obrazem oraz sposób, w jaki wizualność języka manipuluje odczytywanym przekazem. Inna ówczesna grupa powstała wokół pisma „Emigre” z redaktorem i dyrektorem artystycznym Rudym VanderLansem na czele. Pismo to prowadziło wywiady z najważniejszymi postaciami projektowania typograficznego tego okresu ${ }^{41}$. Jako kolejny poruszał temat czytelności tekstu oraz osadzał swoje projekty na obranych przez siebie teoriach. Stworzył krój pisma, który miał na celu „bycie wiarygodnym odzwierciedleniem niedoskonałego języka niedoskonałego świata zamieszkałego przez niedoskonałe istoty [...]”42. Toczą się zatem „wojny o czytelność”33 (legibility wars) projektantów poddających typografię eksperymentom i zwolenników klasycznych rozwiązań. Lata 80. były czasem intensywnego eksperymentowania z formą tekstu opartego na rodzących się wówczas teoriach ${ }^{44}$. Z końcem wieku jednak założenia te schodzą na bok, by zrodzone z nich techniki typograficzne mogły przerodzić się w zwykłe style, łatwiejsze do operowania przez projektantów zajmujących się od teraz głównie sprzedażą produktów rodzących się licznie marek ${ }^{45}$.

\subsection{Wejście w Nową Erę}

Od lat 80. komputer - coraz łatwiej dostępny dla zwykłego konsumenta - staje się nieodłącznym narzędziem pracy projektanta ${ }^{46}$. W ostatniej dekadzie XX wieku projektowanie graficzne zyskuje egalitarny wymiar - niewykwalifikowani twórcy dochodzą do głosu i wystawiają swoje projekty na równi z zawodowymi projektantami ${ }^{47}$. Był to „czas autoekspresji, co zbiegło się z rozpowszechnieniem

${ }^{39}$ R. Poynor, Typografia postmodernistyczna..., s. 131.

${ }^{40}$ I. Camargo, L.M. Reis Velloso, Search for meaning: A study on the Cranbrook Academy of Art's Graphic Design Department, wrzesień 2012, s. 73.

${ }^{41}$ R. Poynor, Typografia postmodernistyczna..., s. 127.

42 Ibidem, s. 129.

43 Ibidem, s. 125.

${ }^{44}$ A. Blauvelt, $W$ stronę krytycznej autonomii, czyli czy projektowanie graficzne może się uratować, w: Widzieć/ Wiedzieć..., red. P. Dędowski, J. Mrowczyk, s. 265.

${ }^{45}$ Ibidem, s. 266.

${ }^{46}$ Mowa tu głównie o Sanach Zjednoczonych, w Polsce komputery osobiste pojawiły się dopiero dekadę później. Zob. J. Mrowczyk, Z. Kolesár, Historia projektowania..., s. 287.

${ }^{47}$ Ibidem, ss. 288-289. 
techniki cyfrowej, a co za tym idzie - z nieograniczonymi możliwościami tworzenia własnych projektów przez osoby spoza dotychczasowego wąskiego grona specjalistów”48. Projektanci muszą się odnaleźć w natłoku prac i różnorodności stylów, nadać kierunek tym zmianom. Odpowiedź przynoszą kultura popularna oraz reklama. W latach 90. kultura popularna powoduje, że pożądamy piękna wygląd przedmiotów użytkowych staje się dla nas tak ważny, że przesłania nam ich naturę, czyli funkcjonalność ${ }^{49}$. Do tego dochodzi reklama oraz kult marki, które promowały indywidualizm i produkty wyrażające własną osobowośćco. Styl to już wyłącznie realizacja estetycznych potrzeb konkretnej jednostki. Projektowanie graficzne traci moc krytyczną - kiedyś określonym działaniom projektowym przyświecała refleksja (Cranbrook Academy lub styl szwajcarski), teraz to jedynie produkt przeznaczony do konsumpcji ${ }^{51}$. Pojawiają się głosy sprzeciwu. W 1999 roku, w piśmie „Emigre” projektanci publikują swój manifest Najpierw rzeczy pierwsze 2000 (nawiązujący do manifestu o tym samym tytule z 1964 roku, w którym w czasie dopiero rodzącej się reklamy już zdawano sobie sprawę, ku czemu zmierza dizajn). Nie akceptują sytuacji, w której się znaleźli, projektowanie sprowadzone zostało do komercji i utraciło swoją pierwotną funkcję społeczną środka komunikacji ${ }^{52}$. Na nowej fali projektowania - niewymagającej kwalifikacji, wspomaganej pracą komputera i będącej na usługach wielkich marek - najwyżej wznosi się David Carson, surfer (lecz nie projektant) z zawodu. Samouk, oczytany w pracach pochodzących ze szkoły Cranbrook, stosował kroje pisma studentów tej uczelni oraz ich metody, sprowadzając je jednak tylko do stylizacji. Pismem, które rozwinęło jego karierę, był „Ray Gun”, od czasów którego projektuje już wyłącznie dla największych marek ${ }^{53}$. Magazyn ten przeznaczony był dla młodego czytelnika, wychowanego w erze cyfrowej na komputerach i wideoklipach emitowanych w telewizji ${ }^{54}$, dla którego naturalnym środkiem przekazu były media cyfrowe, a nie druk ${ }^{55}$.

W 1996 r., wspomniany już Rudy VanderLans, publikuje w magazynie „Emigre” numer pt. Graphic Design and the Next Big Thing (Projektowanie graficzne i następna wielka rzecz). Dochodzi do momentu, w którym stawia pytanie: co

\footnotetext{
${ }^{48}$ Widzieć/ Wiedzieć..., red. P. Dędowski, J. Mrowczyk, s. 85.

49 R. Poynor, Rzecz piękna, w: Widzieć/ Wiedzieć..., red. P. Dędowski, J. Mrowczyk, ss. 254-255.

${ }^{50}$ A. Blauvelt, W stronę krytycznej autonomii, w: Widzieć/ Wiedzieć..., red. P. Dędowski, J. Mrowczyk, s. 266.

${ }^{51}$ Ibidem, s. 264.

${ }^{52}$ Najpierw rzeczy pierwsze 2000, w: Widzieć/ Wiedzieć..., red. P. Dędowski, J. Mrowczyk, ss. 335-336.

${ }^{53}$ Na fali Carsona, „2+3D”, 19 lutego 2010, https://www.2plus3d.pl/artykuly/na-fali-carsona/strona:1 [dostęp: 1.01.2020].

54 J. Mrowczyk, Z. Kolesár, Historia projektowania..., s. 290.

${ }^{55}$ Na fali Carsona, ,2+3D”.
} 

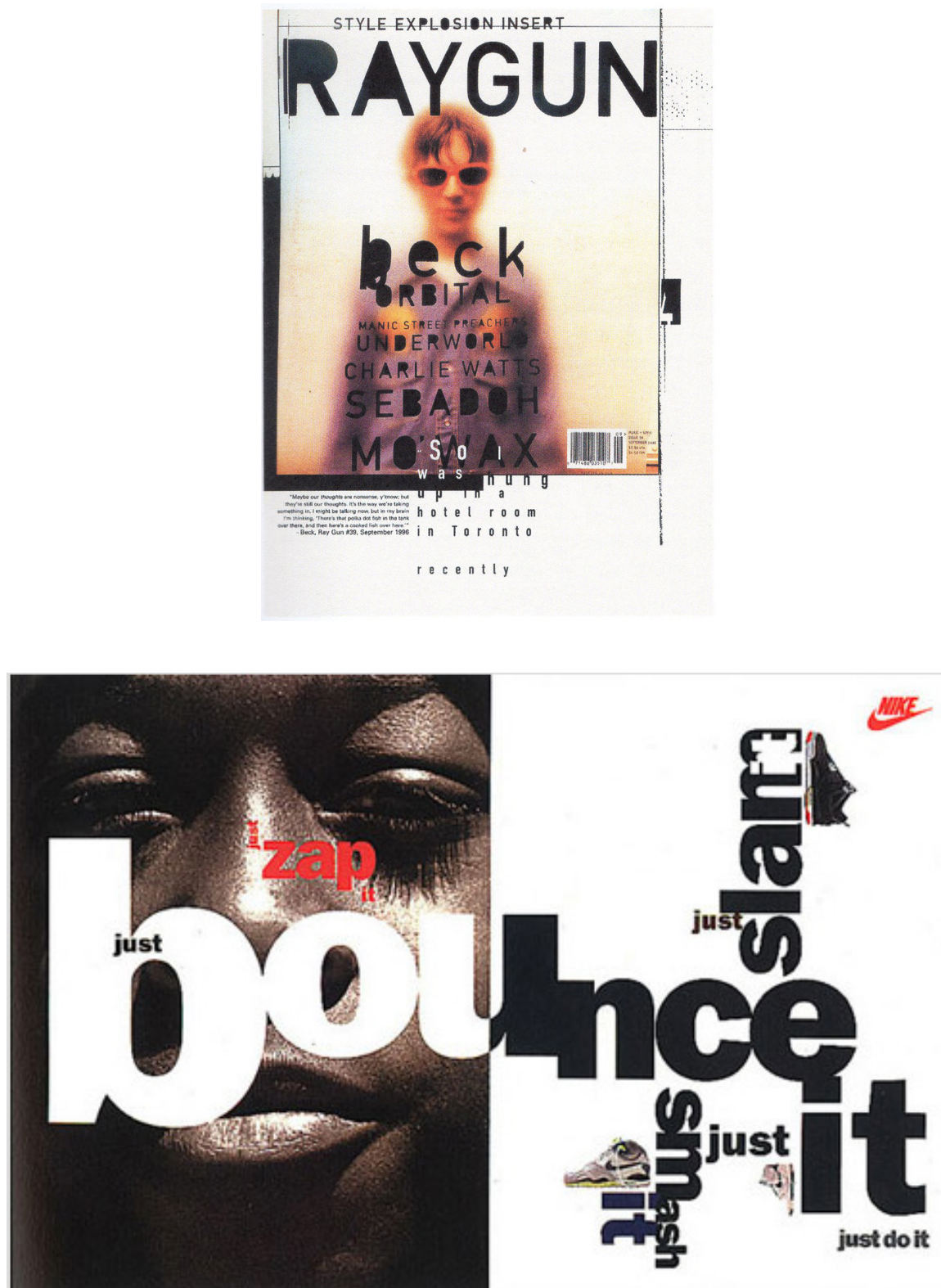

Fot. 11-12. David Carson, okładka czasopisma „Ray Gun” 1996, nr 39, oraz David Carson, reklama Nike

Źródło: fot. 11, J. Mrowczyk, Z. Kolesár, Historia projektowania..., s. 289; fot. 12, H. Davies, David Carson, 21 marca 2011 r., https://hannahdavies27.wordpress.com/2011/03/19/david-carson/ [dostęp: 27.07.2020]. 
dalej? Mówi o Internecie jako możliwej Następnej Wielkiej Rzeczy ${ }^{56}$. David Carson natomiast o końcu ery druku (The End of Print). Twierdzi, że zmieniły się przyzwyczajenia czytelnicze odbiorcy i książka musi się do tego dopasować, dać możliwość samodzielnego dekodowania tekstu ${ }^{57}$.

\section{Następnie rzeczy drugie ${ }^{58}$ - (nie)czytelność i (nie)przezroczystość. Osie refleksji nad typografią}

\subsection{Okno kontra witraż}

Przez lata zmieniały się nie tylko kierunki w praktykowaniu typografii, ale i samo myślenie o niej jako dziedzinie na pograniczu sztuki i rzemiosła. Problem jej funkcji i przeznaczenia stał się polem do dyskusji dla praktyków tej profesji, jak i jej teoretyków. Jedną z nich była Beatrice Warde, amerykańska krytyczka projektowania graficznego i autorka manifestu Kryształowy kielich (1930). Esej Warde był reakcją na XX-wieczne eksperymenty typograficzne modernistycznych artystów ${ }^{59}$. W autorskiej metaforze przyrównuje pożądaną, czyli „przezroczystą” typografię do kielicha z przezroczystego kryształu. W takim naczyniu prawdziwy koneser wina może podziwiać również kolor trunku, w przeciwieństwie do szkła zabarwionego na dany kolor, które przesłoniłoby walory barwy napoju ${ }^{60}$. Inną, bardzo obrazową analogią, jaką formułuje Warde, jest porównanie tekstu do okna. Takie okno znajduje się pomiędzy czytelnikiem a światem wykreowanym przez autora, wynika więc z tego, że aby móc dojrzeć, co mieści się po drugiej stronie, szyba musi być jak najbardziej przeźroczysta (witraż zakłócałby odbiór) ${ }^{61}$. Krytyczka stawia „funkcjonalność” tekstu na pierwszym miejscu, równocześnie nie zaprzeczając, że tekst może być widoczny. Chodzi o wybór, jaki zadrukowana strona daje odbiorcy: tak jak osoba „nie ma [...] patrzeć na okno, lecz przez nie”62, tak „oko [powinno - D.D.] patrzeć przez pismo, a nie koncentrować się na nim”63. Tu teoria typograficzna zaskakująco spotyka się z myślą semiologiczną, ponieważ problem szyby i jej widoczności porusza również francuski semiolog Roland Barthes:

${ }^{56}$ R. VanderLans, Graphic Design and the Next Big Thing, „Emigre”, https://www.emigre. com/Essays/Magazine/GraphicDesignandtheNextBigThing [dostęp: 1.01.2020].

57 Ibidem.

${ }^{58}$ Ponowne nawiązanie do tytułu manifestu projektantów-grafików, autorstwa Kena Garlanda, Najpierw rzeczy pierwsze z 1964 roku (i jego uaktualnionej wersji z 1999 roku, Najpierw rzeczy pierwsze 2000).

59 J. Post, Rewolucja cyfrowa, w: Triumf typografii..., red. H. Hoeks, E. Lentjes, ss. 155 i 159.

${ }^{60}$ B. Warde, Kryształowy kielich, czyli druk powinien być niewidoczny, w: Widzieć/ wiedzieć..., red. P. Dędowski, J. Mrowczyk, ss. 39-40.

${ }^{61}$ Ibidem, s. 43.

62 J. Post, Rewolucja cyfrowa, s. 159.

${ }^{63}$ B. Warde, Kryształowy kielich..., s. 44. 
[...] jeśli siedzę w samochodzie i oglądam krajobraz przez szybę, mogę dowolnie zgrać krajobraz i szybę: raz dostrzegać będę obecność szyby i odległość pejzażu, to znów, na odwrót, przezroczystość szyby i głębię pejzażu ${ }^{64}$.

Barthes odwołując się do metafory szyby, opisywał zjawisko mitu, który ma podwójną naturę. W micie „sens jest zawsze obecny, aby pr z e d s t a w i a ć formę; forma zawsze jest obecna [aby - D.D.] o dda lać sens”65. Podobnie tekst zawiera w sobie treść, ale ma też swoją fizyczną formę, by móc go przekazać, z tą różnicą, że według Warde jego wizualność musi przybliżać treść, a nie odsuwać ją od odbiorcy.

Całkowitym przeciwieństwem praktyk Warde byłby wspomniany już wcześniej amerykański projektant David Carson. Jest on najlepszym przykładem tego, jak bardzo „widoczny” może być tekst. Według Carsona czytelność to „rzecz incydentalna”66. Bycie nieczytelnym nie oznacza nieposiadania przekazu: „nie można nic nie komunikować, ponieważ słowa zawsze są obrazami i zawsze, nawet zanim zostaną przeczytane, niosą ładunek emocjonalny"67. Tej formie typografii, będącej negatywem przezroczystej Wardowskiej, nadaje nazwę inna amerykańska projektantka i teoretyk, Johanna Drucker. Autorka książki The Visible Word: Experimental Typography and Modern Art, 1909-1923 (1994) dzieli typografię na zauważalną ${ }^{68}$ (marked typography) i niezauważalną (unmarked typography). Niezauważalna typografia miałaby reprezentować to, o czym mówiła Warde - nierzucający się w oczy i spełniający swoją funkcję przenoszenia komunikatu tekst, np. literacka prozę i poezję, gdyż są neutralne w swojej formie i tym samym „nie niosą żadnych [... ] oznak typograficznej manipulacji”69. Z drugiej strony typografia zauważalna ma charakter czysto komercyjny, aby móc „sprzedać konkretną ideę czytelnikowi”70. Dzieje się to za pomocą „mocno zauważalnych zabiegów typograficznych, które wyraźnie, a nawet w sposób agresywny, manipulują odczytaniem tekstu"71. Drucker rysuje skrajną opozycję dwóch możliwych rodzajów realizacji tekstu, nie biorąc pod uwagę możliwości istnienia form pośrednich, niewpisujących się w żadną z tych odmian typografii. Słuszność istnienia jednak takiego podziału podważają Megan L. Benton i Paul C. Gutjahr w książce Illuminating Letters: Typography and Literary Interpretation (2010). Proza czy poezja, które Drucker zalicza do tekstów niezauważalnych, są nie mniej widoczne od mocno zauważalnych materiałów reklamowych ${ }^{72}$. Mimo iż na plakatach reklamowych

\footnotetext{
${ }^{64}$ R. Barthes, Mit i znak, tłum. W. Błońska, PIW, Warszawa 1970, s. 42.

${ }^{65}$ Ibidem.

${ }^{66}$ J. Post, Rewolucja cyfrowa, s. 161.

${ }^{67}$ Ibidem.

${ }^{68}$ Takie tłumaczenie zostało użyte w eseju Jacka Posta pt. Rewolucja cyfrowa, s. 160.

${ }^{69}$ Illuminating Letters: Typography and Literary Interpretation, red. Megan L. Benton, Paul

C. Gutjahr, University of Massachusetts Press, 2010, s. 5, tłum. własne.

${ }^{70}$ Ibidem, tłum. własne.

${ }^{71}$ Ibidem, tłum. własne.

72 Ibidem, s. 6.
} 

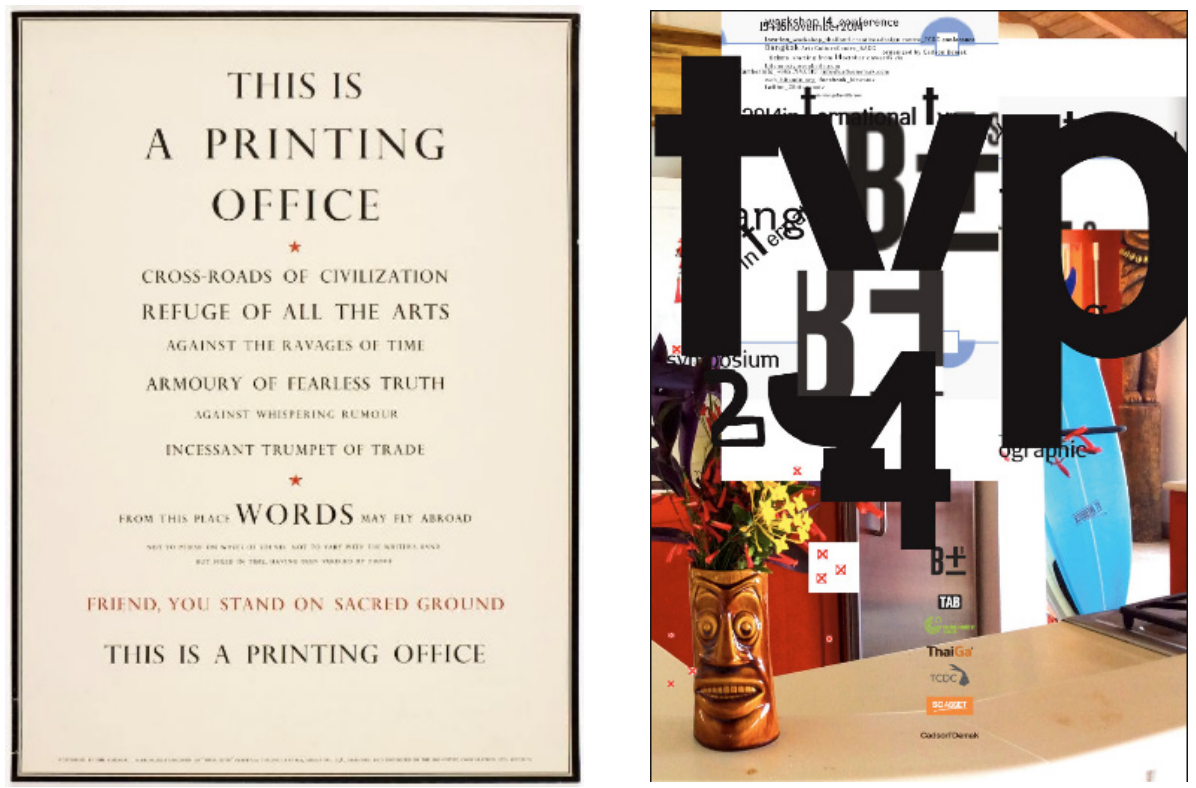

Fot. 13-14. Beatrice Warde This is a Printing Office (To jest drukarnia), 1932 rok; David Carson, plakat na międzynarodowe symposium typograficzne, Bangkok, 2014 rok Źródło: fot. 13, Celebrating Beatrice Warde, 15 października 2014 r., https://ilab.org/articles/ celebrating-beatrice-warde [dostęp: 24.08.2020]; fot. 14, oficjalna strona internetowa Davida Carsona, http://www.davidcarsondesign.com/ [dostęp: 24.08.2020].

obecność tekstu jest znacznie wyraźniejsza, to nadal w obu - książce pisanej prozą i plakacie reklamowym - został użyty tekst, który ma swój krój, wielkość, kolor i rozmieszczenie. Autorzy Illuminating Letters uzasadniają to na przykładzie wystawiania sztuki Hamleta Williama Shakespeare’a w teatrze. Produkcja umieszczająca Hamleta we współczesnych czasach byłaby nie mniej widoczna od klasycznej reprodukcji, ponieważ obie inscenizacje byłyby interpretacjami danego reżysera i osób pracujących przy produkcji, których decyzje mają wpływ na przekaz i odbiór dzieła ${ }^{73}$. Autorzy Illuminating Letters podważają również tezy Warde. W oczywistym nawiązaniu do idei o podobnej funkcji tekstu i okna, jako przeźroczystej tafli szkła oddzielającej dwa światy - w przypadku tekstu, światy autora i czytelnika - autorzy konkludują, że „nieważne jak przeźroczyste byłoby szkło, okno jest wyraźnie widoczne, jeśli spojrzy się na nie pod odpowiednim kątem”74. Pozorna niewidoczność tekstu to wyłącznie efekt nieprzystosowania

\footnotetext{
${ }^{73}$ Ibidem.

${ }^{74}$ Ibidem, tłum. własne.
} 
oka odbiorcy. To jak niewprawione ucho pasjonata muzyki, które z czasem dopiero uczy się słyszeć bardziej subtelne dźwięki - autorzy są zdania, że podobnie przeciętny czytelnik może „wyrobić” sobie oko ${ }^{75}$.

\subsection{Topografia typografii i tekstura tekstu}

W poprzednim podrozdziale doszłam do konkluzji, że tekst niewątpliwie ma swoją fizyczną materię - nawet najbardziej standardowy, czarny druk na białej stronie możemy zobaczyć i opisać. Dzięki temu z opozycji tekstu widzialnego i niewidzialnego można przejść do kolejnej - podziału tekstu na treść i formę. Amerykańska pisarka Susan Sontag źródła tej dychotomii dzieła upatruje w praktykowanym od czasów starożytnych Greków naśladownictwie natury (mimesis) ${ }^{76}$. Jak tłumaczy Sontag:

W tej teorii sztuka [...] jest problematyczna i wymaga obrony. To właśnie jej obrona przyczyniła się do narodzin osobliwego mniemania, zgodnie z którym coś, co nauczyliśmy się nazywać „formą”, jest oddzielne od tego, co określamy mianem „treści”, pojmowanej [...] jako istotna, w przeciwieństwie do formy, którą uznaje za pomocniczą ${ }^{77}$.

W tak zarysowanym obrazie forma ma tylko „pomagać” treści, pośredniczyć między nią a odbiorcą, sama nic nie wnosząc do ogólnego odbioru dzieła. W najlepszym przypadku jest „co najwyżej przezroczystą kładką, po której trzeba przejść w drodze do zdeszyfrowania ukrytej treści”78, pomimo tego, że jest konieczna dla istnienia treści, ponieważ dzieło musi mieć jakąkolwiek formę. Pisarka sprzeciwia się takiej teorii, twierdząc, jak wskazuje Dariusz Czaja, że „w wypadku wielkiej sztuki forma właśnie jest treścią”79, należy „przyjrzeć się temu jak rzecz została napisana”80. Forma więc, dla autorki, staje na równi z treścią, lecz tylko w przypadku wielkich dzieł sztuki. Bardziej stanowczym w obaleniu poglądu o istnieniu dwóch osobnych warstw w dziele był Allen Hori, absolwent Cranbrook Academy of Art, prowadzonej przez wspomnianą wcześniej Katherine McCoy. Typograf „kwestionuje tradycyjne przeciwstawienie czytania oglądaniu i traktuje przestrzeń dzieła jednocześnie jako teoretyczną treść i zmysłową formę - tekst i teksturę”1. Według projektanta granica między nimi jest płynna, każda z tych postaci dzieła

75 Ibidem.

76 S. Sontag, Przeciw interpretacji, w: Przeciw interpretacji i inne eseje, tłum. M. Pasicka, A. Skucińska, D. Żukowski, Karakter, Kraków 2012, ss. 11-12.

77 Ibidem, s. 12.

78 D. Czaja, Przeciw interpretacji, dwutygodnik.com, lipiec 2012, https://www.dwutygodnik. com/artykul/3799-przeciw-interpretacji.html [dostęp: 14.03.2020].

79 Ibidem.

80 Ibidem.

81 E. Lupton, J. Abbott Miller, Projektowanie graficzne a dekonstrukcja, w: Widzieć/ wiedzieć..., red. P. Dędowski, J. Mrowczyk, s. 95. 
może być jednocześnie czytana i oglądana. Na ten temat wypowiedział się również polski dydaktyk Akademii Sztuk Pięknych w Krakowie, Andrzej Bednarczyk. W artykule Kształt nieczytelności artysta pisze o „wielowymiarowości wszelkich realizacji językowych”82, tłumacząc to zagadnienie na przykładzie mówiącej osoby - w skład aktu komunikacji wchodzi wiele pośrednich elementów (gesty, mimika), pod wpływem których docelowe znaczenie, to jest verbum ${ }^{83}$, może się zmienić ${ }^{4}$. Ten sam schemat przekłada na tekst pisany - krój czcionki czy podział tekstu to „pozawerbalne składowe treści” ${ }^{\circ}$, a więc mają, tak samo jak mimika czy gesty w wypowiedzi werbalnej, wpływ na treść przekazu. Treść i forma są więc w tej analogii zależne od siebie. Należałoby więc przyjrzeć się, co wprowadzają w treść dzieła tego rodzaju modyfikacje formalne.

Do podstawowych zabiegów typograficznych kształtujących warstwę graficzną tekstu, które wybrałam do analizy w tej pracy (jest ich znacznie więcej, ograniczę się jednak do pięciu, które uznałam za elementarne), należą: hierarchia, kolor, kroje pisma/fonty, podział strony (layout)/siatka (grid) oraz skala. Przy ich opisie posłużę się książką Gavina Ambrose i Paula Harrisa Typografia (The Fundamentals of Typography, 2008): to kompendium wiedzy o podstawach projektowania typograficznego. Pierwszym zagadnieniem z wyżej wymienionych jest hierarchia. Zdaniem Ambrose i Harrisa hierarchia w typografii „to logiczny, wizualny sposób na wyrażanie ważności różnych elementów tekstu, osiągane dzięki wizualnemu przewodnikowi prowadzącemu po jego strukturze" ${ }^{\text {"6 }}$. Inne źródło podaje, że hierarchia to „w największym skrócie [...] sposób projektowania treści tekstowych z naciskiem na najwyższy poziom czytelności”" ${ }^{\prime 7}$. Pojęcie hierarchii w kontekście tekstu jest więc ściśle związane z jego funkcjonalnością - uporządkowanie pewnych elementów tekstu według hierarchii ma pomóc czytelnikowi w jego odbiorze. By wyróżnić daną część tekstu, można zastosować powiększenie, dodać kolor czy umieścić tekst w widocznym miejscu. By jednak zabiegi te swoją obecnością pomagały w odbiorze tekstu, a nie były jedynie formą ozdoby, należy znaleźć powód, dla którego akurat ten zabieg stosujemy. Autorzy Typografii podkreślają: „kluczem do efektywnej pracy z hierarchią jest znajomość typu informacji zawartych w tekście”"88.

${ }^{82}$ A. Bednarczyk, Kształt nieczytelności, „Zeszyty Artystyczne” 2017, nr 31, Uniwersytet Artystyczny w Poznaniu, s. 16.

${ }^{83}$ Verbum, jak podaje Słownik języka polskiego PWN, oznacza z języka łacińskiego „słowo”, https://sjp.pwn.pl/slowniki/verbum.html [dostęp: 14.03.2020].

${ }^{84}$ A. Bednarczyk, Kształt nieczytelności.

${ }^{85}$ Ibidem.

${ }^{86}$ G. Ambrose, P. Harris, Typografia, Wydawnictwo Naukowe PWN, Warszawa 2008, s. 134.

${ }^{87}$ P. Krzywina, Hierarchia typograficzna, czyli kolejne poziomy dobrego projektu, webwavesms.com, 11 stycznia 2018, https://webwavecms.com/blog/hierarchia-typograficzna-czylikolejne-poziomy-dobrego-projektu [dostęp: 15.02.2020].

${ }^{88}$ G. Ambrose, P. Harris, Typografia, s. 135. 
Następnym aspektem projektu typograficznego jest kolor. Większość tekstów, z jakimi przeciętnie ma się do czynienia, to klasyczny czarny druk na białej stronie. Dlatego wprowadzenie koloru w tekście może zwracać szczególną uwagę. Kolory z reguły kojarzymy z pewnymi właściwościami, „a sposób, w jaki je interpretujemy wynika z psychologii, kultury, religii oraz codziennych przyzwyczajeń i środowiska, w którym żyjemy" " . Kolor jest zależny od kontekstu i wprowadza określone skojarzenia do projektu, w którym występuje. Dlatego również tradycyjne czarno-białe teksty nie są pozbawione tego dodatkowego znaczenia - projekty w tych klasycznych barwach kojarzą się z powagą i profesjonalizmem.

Następnym istotnym zagadnieniem jest kwestia kroju pisma czy fontu. Dzisiaj określenia te używane są zamiennie, mimo iż ich znaczenia są stosunkowo różne. Krojem pisma określa się „obraz kompletu znaków pisma o jednolitych i spójnych cechach graficznych: stylu, rytmie, proporcji, kształcie szeryfów”90. Font z kolei to „fizyczny środek stosowany do tworzenia kroju pisma, obojętnie czy jest to maszyna do pisania, wzornik [czy - D.D.] bloki maszyny drukarskiej [...]"91. Każdy krój charakteryzuje się pewnymi cechami zależnymi od tego, w jaki sposób został zaprojektowany: „w oparciu o strukturę siatki, [...] narysowany odręcznie [...] oparty na wyrytych literach, jak tradycyjne formy typograficzne"92 czy wygenerowany komputerowo. W typografii rozróżnia się również kroje szeryfowe i bezszeryfowe - jedno z najważniejszych rozgraniczeń krojów pisma ${ }^{93}$. Szeryfami nazywa się „elementy ozdobne pisma [...] wywodzące się z kutych w kamieniu napisów starożytnego Rzymu"94. Ze względu na swoje pochodzenie uważane są za fonty eleganckie. Analogicznie, kroje bezszeryfowe uznawane są za nowoczesne ze względu na swoją prostotę.

Kolejnymi z głównych zagadnień w typografii są podział strony (layout) oraz siatka (grid). Traktują one o podobnym problemie. Na stronie może znajdować się znacznie więcej elementów niż sam tekst, między innymi ilustracje czy fotografie. Również sam tekst nie musi być jednolitym blokiem. W rozmieszczeniu tych wszystkich składowych strony pomaga siatka będąca „niczym rusztowanie, które kształtuje organizację elementów na stronie”95. Oprócz siatek symetrycznych możemy też wyróżnić siatki asymetryczne, te wciąż jednak pomagają zachować

89 A. Tulibacka, Znaczenia i wpływ podstawowych kolorów na odbiorcę. Szybki przegląd podstawowych kolorów, grafmag.pl, 21 lipca 2014, https://grafmag.pl/artykuly/znaczenia-iwplyw-podstawowych-kolorow-na-odbiorce [dostęp: 15.03.2020].

90 J. Fabijańczyk, Typografia od A do Z - czcionki, fonty i zasady ich stosowania Internecie, whitepress.pl, https://www.whitepress.pl/baza-wiedzy/499/typografia-od-a-do-z-\%E2\%80\%93czcionki-fonty-i-zasady-ich-stosowania-w-internecie [dostęp: 15.03.2020].

91 G. Ambrose, P. Harris, Typografia, s. 56.

92 Ibidem, s. 146.

93 J. Fabijańczyk, Typografia od A do Z...

94 Ibidem.

95 G. Ambrose, P. Harris, Typografia, s. 76. 

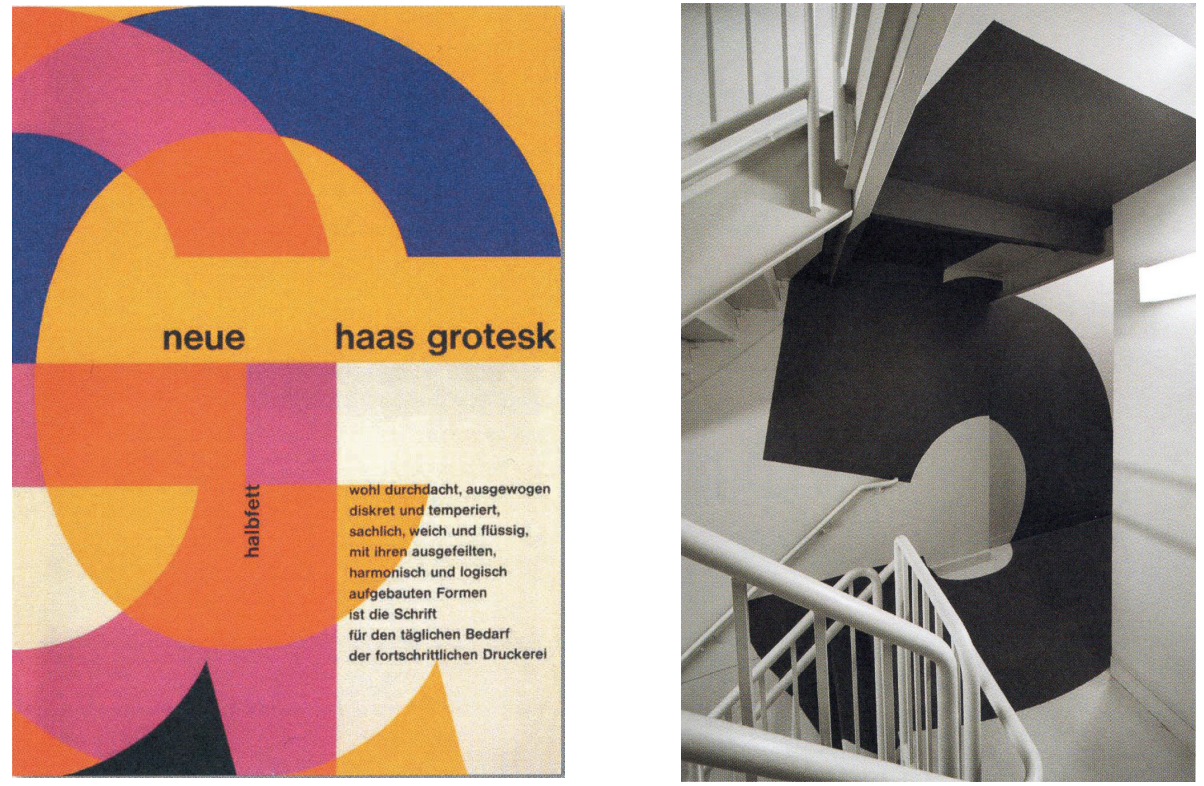

Fot. 15-16. Max Miedinger i Eduard Hoffmann, plakat Neue Haas Grotesk, 1957 rok; Paula Scher, element oznakowania klatki schodowej w budynku firmy medialnej Boomberg, Nowy Jork, 2005 rok

Źródło: fot. 15, J. Mrowczyk, Z. Kolesár, Historia projektowania..., s. 223; fot. 16, J. Mrowczyk, Z. Kolesár, Historia projektowania..., s. 301.

porządek tekstu ${ }^{96}$. Layout natomiast (ang. układ) to po prostu „projekt układu graficznego"97, w przeciwieństwie do siatki nie musi być uporządkowany, przykładem może być poezja konkretna ${ }^{98}$.

Ostatnie z przywołanych wyżej zagadnień odnośnie do typografii związane jest z pojęciem skali. Tekst, słowa czy pojedyncze litery lub cyfry zdobią nie tylko strony magazynów, książek czy ekrany komputerów i telefonów komórkowych. Typografia jest również obecna w przestrzeni miejskiej w postaci billboardów, oznakowania przestrzeni (parkingów, budynków i ulic), szyldów sklepów czy graffiti.

${ }^{96}$ Ibidem, s. 79.

${ }^{97}$ Layout - czym jest i z jakich części się składa?, wizualni.pl, https://wizualni.pl/layout-czym-jakich-czesci-sie-sklada/ [dostęp: 15.03.2020].

98 „Nurt wykorzystujący zapis językowy jako tworzywo wizualne, akcentując jego materialność”. Cyt. za: Stanisław Dróżdż: Poezja konkretna w przestrzeni miasta, Kulturalne Ingrediencje, 22 grudnia 2017, http://kulturalneingrediencje.blogspot.com/2017/12/stanisaw-drozdz-poezja-konkretna-w.html [dostęp: 15.03.2020]. 


\subsection{Czytelna nieczytelność}

Czytelność w języku polskim definiowana jest zwięźle, jako „łatwość odczytania, zrozumiałość" ${ }^{99}$. W innych językach istnieje jednak więcej określeń opisujących to zjawisko i tym samym dające lepszy na niego ogląd. Angielskie legibility oraz readability odnoszą się do pojęcia czytelności, niemieckie Unleserlichkeit i Unlesbarkeit zdają sprawę z form nieczytelności tekstu. W ramach tych pojęć wyróżnić można jeszcze jeden podział, łącząc Unlesbarkeit z legibility oraz Unleserlichkeit z readability. Pierwsza z tych par traktowałaby o czytelności lub nieczytelności jedynie w kontekście znaków pisma - czy są dla czytelnika rozpoznawalne jako część jakiegoś systemu znaków ${ }^{100}$. Druga natomiast opisywałaby (nie)czytelność tekstu jako całości - czy jako kompletna forma dany zapis jest możliwy do odczytania ${ }^{101}$. Problematyka pojęcia nieczytelności zaowocowała powstaniem wystawy pod kuratorstwem Marty Smolińskiej Nieczytelność. Konteksty pisma. Prace z ekspozycji oraz teksty zamieszczone w jednym z numerów „Zeszytów Artystycznych”102, poświęconemu tej wystawie, posłużą do zobrazowania wyżej wymienionych form (nie)czytelności.

W pierwszej kolejności przybliżyć należy pojęcia Unlesbarkeit i legibility. Pierwsze z nich oznacza, że „znaki nie pełnią funkcji przekazywania sensów lub reprezentują system znaków, którego nie znamy”103. Drugie pojęcie, legibility, „odnosi się do zdolności rozróżniania jednej litery od drugiej poprzez typowe fizyczne cechy w konkretnym kroju pisma"104. Działają one na poziome mikrotypografii, ponieważ tak jak ona obejmują „to, co rozgrywa się między literami, wyrazami i wierszami” ${ }^{105}$. Możemy mieć do czynienia z zapisem, który rozpoznajemy jako tekst, lecz jest dla nas nieczytelny, ponieważ nie znamy jego systemu znaków. Może być to też zapis, który tylko pozornie przypomina znany czytelnikowi system, więc ostatecznie nie pozwala mu na odczytanie jego treści. Za przykład może posłużyć twórczość Macieja Sieńkowskiego z wystawy Nieczytelność. Konteksty

99 Słownik języka polskiego PWN, https://sjp.pwn.pl/slowniki/czytelno\%C5\%9B\%C4\%87. html [dostęp: 28.12.2019].

${ }^{100}$ G. Unger, Kiedy czytamy, w: Widzieć/ Wiedzieć..., red. P. Dędowski, J. Mrowczyk, s. 172.

101 Ibidem.

102 M. Smolińska, Nieczytelność: konteksty pisma i palimpsesty, „Zeszyty Artystyczne” 2017, nr 2(31), Uniwersytet Artystyczny w Poznaniu.

${ }^{103}$ E. Schumacher, Die Ironie der Unverständlichkeit. Johann Georg Hamann, Friedrich Schlegel, Jacques Derrida, Paul de Man, Frankfurt 2000, s. 333; A. Gilbert, Bewegung im Stillstand. Erkundungen des Skripturalen bei Carlfriedrich Claus, Elizaveta Mnatsakanjan, Valeri Scherstjanoi Und Cy Twombly, Bielefeld 2007, ss. 31-32; C. Dworkin, Reading the Illegible, Evaston 2003, s. XXIII. Cyt. za: M. Smolińska, Nieczytelność..., s. 35.

${ }^{104}$ G. Ambrose, Typografia, s. 150.

105 H.P. Willberg, O czym będziemy mówić?, kultura.onet.pl, 2 czerwca 2005 r., https:// kultura.onet.pl/fragmenty-ksiazek/o-czym-bedziemy-mowic/hdm66pn [dostęp: 7.04.2020]. 
pisma. Artysta stworzył własny system znaków. Opierając się na alfabecie innego twórcy, Władysława Strzemińskiego, dokonuje stopniowego jego uproszczenia, tym samym tracąc jego czytelność ${ }^{106}$. Ostatecznie dochodzi do takiej formy, w której „ogranicza się tylko do sprowadzenia liter alfabetu do figury koła i jego podziałów”107. Jest możliwe napisanie nim tekstu i odbiorca byłby świadom, że jest to właśnie tekst. Nie byłby jednak w stanie odczytać jego treści, ponieważ musiałby najpierw poznać ten system i go sobie przyswoić. Takie znaki:

Stają się dekoracyjną i splątaną linią, irytującą odbiorców swoją nieczytelnością, lub znakami, przypominającymi litery jakichś nieznanych, enigmatycznych alfabetów. [...] Nawiązując do kształtów liter i słów, przewrotnie sugerują, że niosą sens, a tymczasem tej funkcji się uchylają ${ }^{108}$.

Druga wyróżniona para pojęć to Unleserlichkeit i readability. Niemiecki wyraz, odnoszący się do formy tekstu, oznacza dokładniej „nieczytelność zachodzącą w ramach systemu znaków, który świetnie znamy, a spowodowaną [...] niechlujstwem zapisu lub bazgroleniem” ${ }^{109}$. Podobnie angielskie readability „,oznacza[jące] właściwości tekstu lub designu, które wpływają na zdolność ich rozumienia”110. W tym ujęciu tekst jest zapisany znanym czytelnikowi alfabetem, lecz jego ostateczna forma przedstawienia jest niemożliwa do odczytania. Może to oznaczać nakładający się na siebie tekst, ucięcie go w połowie, rozmazanie, zamazanie, rozmycie czy, już wcześniej wspomniany, niestaranny charakter pisma. Doprecyzowując, oba hasła dotyczą sfery makrotypografii. Jest to „koncepcja, projekt, idea, całościowy rozkład elementów”"111. Elementy, które w jednym układzie tworzą czytelny przekaz, w innym mogą go zakłócić. Za przykład tego typu nieczytelności mogą posłużyć prace Brigitte Kowanz, jak poprzednie, również zaprezentowane na wystawie w galerii Art Stations. Artystka stworzyła serię atrakcyjnych wizualnie, lecz niedających się odczytać zapisów „angielskich słów, [tak - D.D.] by zachowały charakter ręcznego pisma oraz - poprzez wygięcie każdego z nich w formę okręgu - stały się ornamentem”"112. Nieczytelność projektu spotęgowana została dodatkowo przez zastosowanie świecących się neonowych rurek. Dobrze więc znany zapis słowa staje się nie do rozpoznania przez serię zabiegów - z powodu

${ }^{106}$ K. Gliszczyński, Na zakręcie sztuki. Nieczytelny alfabet Macieja Sieńkowskiego, w: M. Smolińska, Nieczytelność..., s. 145.

107 Ibidem.

108 „Nieczytelność. Konteksty pisma” w Art Stations, magazyn szum.pl, 30 marca 2016 r., https://magazynszum.pl/nieczytelnosc-konteksty-pisma-w-art-stations/ [dostęp: 7.04.2020].

109 E. Schumacher, Die Ironie der Unverständlichkeit. Johann Georg Hamann, Friedrich Schlegel, Jacques Derrida, Paul de Man, Frankfurt 2000, s. 333; A. Gilbert, Bewegung im Stillstand..., ss. 31-32; C. Dworkin, Reading the Illegible, s. XXIII. Cyt. za: Marta Smolińska, Nieczytelność..., s. 35.

${ }^{110}$ G. Ambrose, Typografia, s. 150.

111 H.P. Willberg, O czym będziemy mówić?

${ }^{112}$ M. Smolińska, Nieczytelność..., s. 50. 

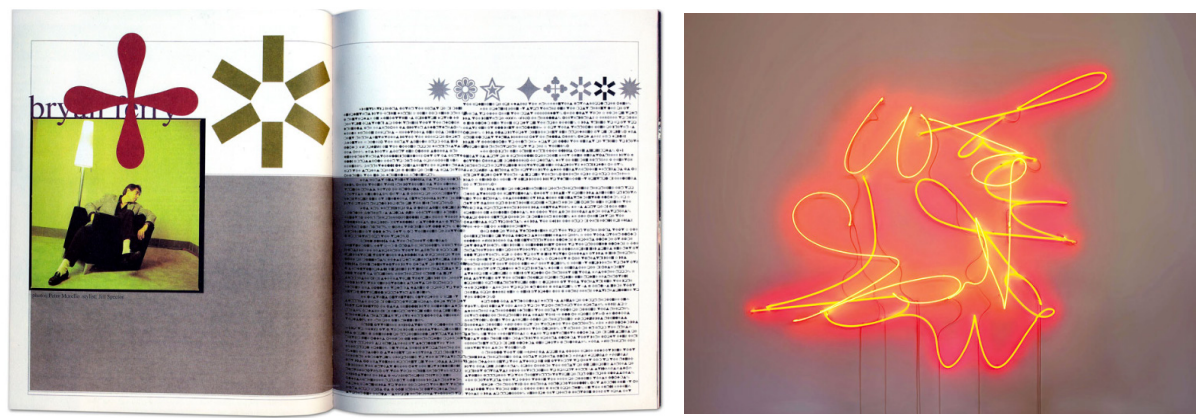

Fot. 17-18. David Carson, rozkładówka magazynu „Ray Gun”, 1994 rok; Brigitte Kowanz, neon Beyond Words, 2010 rok

Źródło: fot. 17, Anti-grid Design Icon David Carson Says Computers Make You Lazy + Indie Magazines Needs To Liven Up, Emily Gosling, Aiga Eye on Design, 12 sierpnia 2019 r., https:// eyeondesign.aiga.org/anti-grid-icon-david-carson-on-why-computers-make-you-lazy-and-indiemag-design-needs-to-liven-up/ [dostęp: 8.04.2020]; fot. 18, R. Fuchs, Brigitte Kowanz, 31 marca 2016 r., https://flash---art.com/article/brigitte-kowanz/ [dostęp: 24.08.2020].

formy koła nie wiadomo, gdzie wyraz się zaczyna, a gdzie kończy, a światło dodatkowo rozmywa nam kształty, które już wcześniej przez zastosowanie pisma ręcznego mogły być mało czytelne ${ }^{113}$. Rozwiązania zastosowane w tej pracy spowodowały, że pojedyncze słowa stają się nieczytelne. Z drugiej strony, próby zwiększania czytelności zapisu mogą mieć odwrotny efekt od zamierzonego i również sprawiać, że dany zapis staje się niemożliwy do odczytania: „paradoksalnie przesadna czytelność [...] także prowadzi do nieczytelności”"114. Takim zabiegiem jest na przykład zwiększanie rozmiaru pojedynczych liter czy znaków interpunkcyjnych. W pracy Und Punkt z 2013 roku Pompéry wybrała kilkanaście powieści miłosnych, wyodrębniła z każdej ostatnią postawioną kropkę i powiększyła je do nieproporcjonalnie dużych rozmiarów ${ }^{115}$.

\subsection{Ciałopisanie i ciało tekstu}

Kolejnym ciekawym zagadnieniem dotyczącym typografii jest „cielesność” tekstu oraz jego związki z ciałem. Pojęcie ciałopisania jest polskim odpowiednikiem angielskiego pojęcia „bodygraphy”, stworzonego przez Małgorzatę Dawidek dla opisania kierunku jej twórczości. Za pomocą terminu „bodygraphy” artystka chce

113 W. Delikta, Aporie pisma, magazyn.o.pl, 23 marca 2016 r., http://magazyn.o.pl/2016/ wojciech-delikta-aporie-pisma/\#/ [dostęp: 8.04.2020].

114 „Nieczytelność. Konteksty pisma”...

115 A. Workowski, Filozof w krainie nieczytelności, w: M. Smolińska, Nieczytelność..., s. 64. 
przybliżyć odbiorcom jej dzieł „cielesność, która jest zarówno nośnikiem pisma, jak i pismem samym w sobie”116. Słowo „bodygraphy” samo dobrze tłumaczy tematykę, jaką oddaje: „body, czyli ciało i - graphy, które można rozumieć jako zapis”117. Ciałopisanie, czy inaczej bodygraphy, oznaczać więc może dwa zjawiska: pisania na ciele (by ukazać niemożliwe do wypowiedzenia stany z nim związane) oraz pisania ciałem (proces ucieleśniania tekstu, którego efektem byłoby jego materialne „ciało” - ciało tekstu). Za przykłady tych zjawisk posłużą prace artystki.

W pierwszej kolejności należałoby poruszyć pojęcie ciałopisania (bodygraphy) rozumianego jako „pisanie na ciele”, ponieważ głównie na tym aspekcie swojej twórczości skupia się Dawidek. W cyklu prac fotograficznych „Teksty Ciała” (Body Texts) artystka przedstawiła swoje ciało pokryte niekończącym się ciągiem odręcznie pisanego tekstu. Dawidek utrwaliła na nim każde swoje fizyczne doświadczenie i umiejscowiła je dokładnie tam, gdzie zogniskowany był ból czy dyskomfort, które odczuwała w związku z przechodzoną przez nią chorobąą ${ }^{118}$. Artystka w tej serii prac podkreśla, że „nie da się zwerbalizować emocji w taki sposób, by mieć poczucie totalnej przyległości słowa do uczucia [...] szczególnie ból jest niewypowiadany”119. By móc więc jak najbardziej przybliżyć odbiorcy, co odczuwa, dopasowuje tekst do konkretnych miejsc na ciele. Choć same słowa nie potrafią w pełni przedstawić doświadczenia Dawidek, to fakt ich umieszczenia na rękach, nogach czy tułowiu przybliża artystkę stopniowo do sukcesywnego wyartykułowania swoich przeżyć. Warto również zauważyć, że zabiegi, jakie zastosowała autorka, przypominają w swojej formie tatuaże. Obie formy zapisu, ciałopisania Dawidek i tatuowania się, służą zapamiętywaniu czegoś. W „Tekstach Ciała” jest to próba zapisania doświadczeń fizycznych, tatuaże natomiast często upamiętniają ważne wydarzenia z życia na gruncie emocjonalnym, niezwiązane bezpośrednio z ciałem.

Bodygraphy to też ciałopisanie rozumiane jako „pisanie ciałem”. Problematykę tego zagadnienia bardzo dobrze obrazuje seria nagrań wideo Dawidek pt. Bodygraphy, w których „słowo i emocje zostały zastąpione przez gest” ${ }^{120}$. Autorka w tych pracach niczego nie zapisuje, wykonuje jedynie same ruchy ręki, jak gdyby rzeczywiście pisała: „ponownie używa własnego ciała - tym razem, by uczynić zeń figurę, performatywnie wpisaną w język ciała oraz naśladującą gestykulację i jako wyraz emocji”"121. Ciało „aktywnie włącza się w proces pisania”122. Wiele fizycz-

${ }^{116}$ M. Dawidek, O pisaniu ciałem, w: M. Smolińska, Nieczytelność..., s. 103.

117 A. Komorowska, Bodygraphy - Małgorzata Dawidek, funkielnowka.wordpress.com, 11 maja 2016, https://funkielnowka.wordpress.com/2016/05/11/bodygraphy-malgorzata-dawidek/ [dostęp: 9.04.2020].

118 A. Komorowska, Bodygraphy...

119 Małgorzta Dawidek. Bodygraphy, wydarzenia.o.pl., 7 kwietnia 2016, http://wydarzenia.o.pl/2016/04/malgorzata-dawidek-bodygraphy-galeria-wozownia-torun/\#/ [dostęp: 9.04.2020].

${ }^{120}$ A. Komorowska, Bodygraphy...

${ }^{121}$ Małgorzta Dawidek. Bodygraphy.

122 Ibidem. 

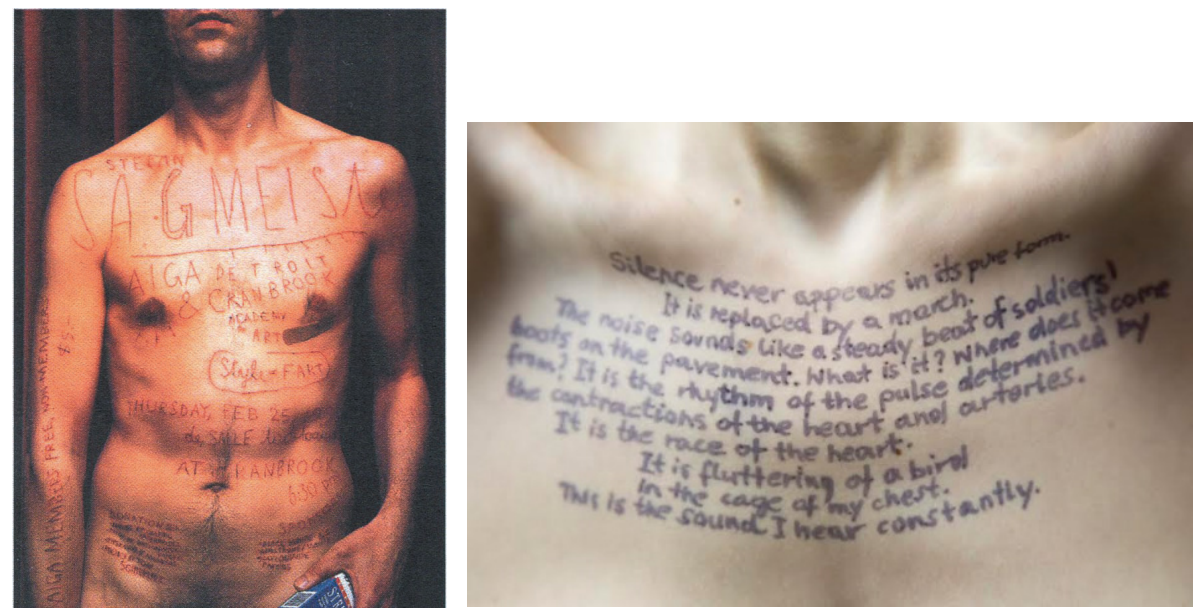

Fot. 19-20. Stefan Sagmeister, plakat promujący wykład w Cranbrook Academy of Art, 1999 rok; Małgorzata Dawidek, Bodygraphy, 2016 rok

Źródło: fot. 19, J. Mrowczyk, Z. Kolesár, Historia projektowania..., s. 324; fot. 20, Małgorzta Dawidek. Bodygraphy, 7 kwietnia 2016 r., http://wydarzenia.o.pl/2016/04/malgorzata-dawidekbodygraphy-galeria-wozownia-torun/\#/ [dostęp: 24.08.2020].

nych aspektów z nim związanych ma wpływ na to, jak ostatecznie wygląda tekst, a dokładniej „ciało tekstu” (body of the text). To „ciało” tekstu jest materialnym efektem procesu pisania. Znaczenie mają wówczas różne czynniki tej czynności: prędkość i nacisk dłoni, kaligraficzna staranność lub jej brak, wybór narzędzia oraz podłoża, charakterystyczne dla danej osoby kształty i linie czy obecność podkreśleń, zakreśleń, przekreśleń, dopisków i zaznaczeń. Ten materialny aspekt tekstu widoczny jest w pracach Dawidek z cyklu „Repozytorium”, czyli dziennika prowadzonego przez artystkę. Tu ponownie Dawidek poszukuje związków ciała z tekstem, lecz w przeciwieństwie do prac z Bodygraphy, efektem tej gestykulacji jest fizycznie obecny zapis:

[...] czasem Dawidek ledwie dotyka powierzchni papieru ołówkiem lub - przeciwnie mocno go dociska, sugerując realną obecność piszącego ciała i podkreślając zmysłowo-czasowy wymiar ciałopisania ${ }^{123}$.

Utrwalony w piśmie tekst niesie za sobą pamięć fizycznego ruchu i czasu, w jakim został stworzony. Niekiedy sam akt zapisu jest ważniejszy od tego, co zostało napisane. Dawidek w „Repozytoriach” „zapisuje teksty warstwowo, piętrzy wersy jedne na drugich, kwestionując ich czytelność”124. Liczy się sama czynność pisania

${ }^{123}$ Ibidem.

${ }^{124}$ M. Smolińska, Nieczytelność..., s. 52. 
i jej efekt materialny, a nie treść tekstu. Teksty te są nacechowane emocjonalnie: „jest to zapis, który nie może zaistnieć bez powołującego go gestu ciała i utrzymującej ów gest emocji” ${ }^{125}$. Artystka mocno podkreśla istotność fizycznego zaangażowania ciała w proces pisania, którego efektem jest „nie pojedynczy, abstrakcyjny znak, ale znak i stojące za nim drżenie ręki, pochylenie się, wdech, nerwowość”126.

\section{Zakończenie}

Reasumując, tekst to złożone medium mające, poza treścią, również swoją materialną naturę, która pozostaje nie bez znaczenia dla ostatecznego odbioru przekazu. Tam, gdzie język zawiódł, lub gdy nie da się odczytać tekstu z powodu jego tradycyjnie rozumianej nieczytelności, forma tekstu „dopowiada” to, czego sama treść nie jest w stanie przekazać. Potrafi również całkowicie zastąpić rolę słów. Na podstawie niniejszej pracy można zauważyć, że zjawisko wizualności tekstu jest bardzo złożone, mimo że zapewne dla większości wydaje się niedostrzegalne. Materialność tekstu jednak istnieje. Powstaje - choć wciąż nie dość liczna - literatura poświęcona temu zagadnieniu oraz wiele ciekawych projektów typograficznych - części z nich poświęciłam w tej pracy uwagę. Nawet w codziennym życiu można niejednokrotnie natknąć się na zjawisko wizualności tekstu: napisana odręcznie lista na zakupy będzie się różnić od atrakcyjnej wizualnie rozkładówki w czasopiśmie. Tekst jest wszędzie obecny, widoczny i zróżnicowany wizualnie, wystarczy zwrócić na niego uwagę i skierować ku niemu wzrok.

\section{Literatura}

Ambrose G., Typografia, Wydawnictwo Naukowe PWN, Warszawa 2008.

Barthes R., Mit i znak, eseje, tłum. W. Błońska, PIW, Warszawa 1970.

Bernhardt S.A., Seeing the Text, „College Composition and Communication” 1986, nr 1(37), National Council of Teachers of English.

Camargo I., Reis V., Leonardo M., Search for meaning: A study on the Cranbrook Academy of Art's Graphic Design Department, 2012.

Carson D., Blackwell L., The End of Print: The Graphic Design of David Carson, Laurence King Publishing, 1995.

Dereń E., Polański E., Wielki Słownik Języka Polskiego, red. Arkadiusz Latusek, PWN, Kraków 2008.

Dyskursy widzialności. Słowa a obrazy, red. P. Sarna, M. Sęk-Iwanek, Wydawnictwo Uniwersytetu Śląskiego, Katowice 2016.

Eco U., Nieobecna struktura, tłum. Adam Weinsberg, Paweł Bravo, Wydawnictwo KR, Warszawa 1996.

125 M. Dawidek, O pisaniu ciałem, s. 102.

${ }^{126}$ Ibidem. 
Fajfer Z., Liberatura, czyli literatura totalna. Teksty zebrane z lat 1999-2009, red. Katarzyna Bazarnik, Korporacja Ha!art, Kraków 2010.

Frutiger A., Człowiek i jego znaki, tłum. Czesława Tomaszewska, Wydawnictwo Do, Wydawnictwo Optima, 2003.

Hochuli J., Detal w typografii, d2d.pl, Kraków 2018.

Illuminating Letters: Typography and Literary Interpretation, red. Gutjahr P.C., Benton M.L., University of Massachusetts Press, Amhrest and Boston 2010.

Kawka M., Komunikowanie wizualne a nauka o mediach - współczesność i perspektywy, „Media i Społeczeństwo”, 2015, nr 5, Repozytorium Uniwersytetu Jagiellońskiego.

Komunikacja wizualna w prasie i mediach elektronicznych, red. K. Wolny-Zmorzyński, Poltext, Warszawa 2013.

Kress G., Leeuwen T. van, Reading Images. The Grammar of Visual Design, Routledge Taylor \& Francis Group, Londyn-Nowy York 2006.

McCoy K., Frej D., Typography as Discourse, 1988.

McCoy K., McCoy M., Cranbrook Design: The New Discourse, The Cranbrook Academy of Art, 1990.

Meggs P.B., Megg's History of Graphic Design, VI edycja, John Wiley \& Sons, Inc., New Jersey 2016.

Mitchell W.J.T., Zwrot piktorialny, „Kultura Popularna” 2009, nr 1(23).

Mrowczyk J., Kolesár Z., Historia projektowania graficznego, tłum. J. Goszczyńska, Karakter, Kraków 2018.

Sarzyńska-Putowska J., Komunikacja wizualna - wybrane zagadnienia, Fundacja im. Joanny Sarzyńskiej-Putowskiej przy Katedrze Komunikacji Wizualnej Wydziału Form Przemysłowych Akademii Sztuk Pięknych im. Jana Matejki w Krakowie, Kraków 2002.

Sierotwiński S., Słownik terminów literackich, Zakład Narodowy im. Ossolińskich Wydawnictwo, Wrocław-Warszawa-Kraków-Gdańsk-Łódź 1986.

Słownik terminologiczny sztuk pięknych, red. K. Kubalska-Sulkiewicz, Wydawnictwo Naukowe PWN, Warszawa 2012.

Słownik terminów literackich, red. J. Sławiński, Zakład Narodowy im. Ossolińskich Wydawnictwo, Warszawa 1988.

Smolińska M., Nieczytelność: konteksty pisma, „Zeszyty Artystyczne” 2017, nr 2(31), Uniwersytet Artystyczny w Poznaniu.

Sontag S., Przeciw interpretacji i inne eseje, tłum. M. Pasicka, A. Skucińska, D. Żukowski, Karakter, Kraków 2012.

Sudjic D., Język rzeczy, Karakter, Kraków 2013.

Tekst, słowo, obraz, red. E. Mikuła, Wydawnictwo Uniwersytetu Łódzkiego, Łódź 2018.

Triumf typografii. Kultura, komunikacja, nowe media, red. H. Hoeks, E. Lentjes, tłum. Magdalena Komorowska, d2d.pl, Kraków 2017.

Twyman M., Typography without words, „Visible Language” 1981, nr 1(15).

Tyczkowski K., Lettera Magica, Wydawnictwo Polski Drukarz Sp. z.o.o., Łódź 2005.

Widzieć/ wiedzieć. Wybór najważniejszych tekstów o dizajnie, red. P. Dębowski, J. Mrowczyk Karakter, Kraków 2015. 


\section{Źródła internetowe}

Czaja D., Przeciw interpretacji, dwutygodnik.com, lipiec 2012, URL: https://www.dwutygodnik.com/artykul/3799-przeciw-interpretacji.html [dostęp: 14.03.2020].

Delikta W., Aporie pisma, magazyn.o.pl, 23 marca 2016 r., http://magazyn.o.pl/2016/wojciech-delikta-aporie-pisma/\#/ [dostęp: 8.04.2020].

Fabijańczyk J., Typografia od A do Z - czcionki, fonty i zasady ich stosowania Internecie, whitepress.pl, https://www.whitepress.pl/baza-wiedzy/499/typografia-od-ado-z-\%E2\%80\%93-czcionki-fonty-i-zasady-ich-stosowania-w-internecie [dostęp: 15.03.2020].

Gieracka M., https://mfiles.pl/pl/index.php/Komunikacja_wizualna [dostęp: 28.12.2019].

Gosling E., Anti-grid Design Icon David Carson Says Computers Make You Lazy + Indie Magazines Needs To Liven Up, Aiga Eye on Design, 12 sierpnia 2019 r., https://eyeondesign.aiga.org/anti-grid-icon-david-carson-on-why-computers-make-you-lazy-andindie-mag-design-needs-to-liven-up/ [dostęp: 8.04.2020].

Harrison J., Stefan Sagmeister, https://unitxbook1.wordpress.com/2015/09/23/stefan-sagmeister/ [dostęp: 11.04.2020].

Hurkacz M., Typografia, 15 listopada 2009 r., https://liternictwo.asp.krakow.pl/?p=449 [dostęp: 28.12.2019].

Kłos A., Styl psychodeliczny w projektowaniu graficznym, 20 kwietnia 2016 r., https://retroavangarda.com/styl-psychodeliczny-w-projektowaniu-graficznym/ [dostęp: 1.01.2020].

Kłos A., MERZ - Kurta Schwittersa połq̨zenie sztuki z życiem, 20 maja 2016 r., https:// retroavangarda.com/merz-kurt-schwitters/ [dostęp: 1.01.2020].

Komorowska A., Bodygraphy - Małgorzata Dawidek, funkielnowka.wordpress.com, 11 maja 2016 r., https://funkielnowka.wordpress.com/2016/05/11/bodygraphy-malgorzata-dawidek/ [dostęp: 9.04.2020].

Krzywina P., Hierarchia typograficzna, czyli kolejne poziomy dobrego projektu, webwavesms.com, 11 stycznia 2018 r., https://webwavecms.com/blog/hierarchia-typograficznaczyli-kolejne-poziomy-dobrego-projektu [dostęp 15.02.2020].

Layout - czym jest i z jakich części się składa?, wizualni.pl, https://wizualni.pl/layout-czym-jakich-czesci-sie-sklada/ [dostęp: 15.03.2020].

Małgorzta Dawidek. Bodygraphy, wydarzenia.o.pl, 7 kwietnia 2016 r., http://wydarzenia.o.pl/2016/04/malgorzata-dawidek-bodygraphy-galeria-wozownia-torun/\#/ [dostęp: 9.04.2020].

Moriarty C., Breakell S., Anthony Froshaug Archive, Archives Hub: Design Archives, 2007 i 2009, https://archiveshub.jisc.ac.uk/designarchives/archives/3c6fdf0e-108b-306e-ac7b-2520e0cfafa4 [dostęp: 14.03.2020].

Mrożek J.A., Bauhaus. Burzliwa historia i utrwalony mit, „2+3D”, 23 lipca 2013 r., https://2plus3d.pl/artykuly/bauhaus-burzliwa-historia-i-utrwalony-mit [dostęp: 1.01.2020].

Na fali Carsona, „2+3D”, 19 lutego 2010 r., https:/www.2plus3d.pl/artykuly/na-fali-carsona/strona:1 [dostęp: 1.01.2020].

Neville Brody, https://www.famousgraphicdesigners.org/neville-brody [dostęp: 1.01.2020].

„Nieczytelność. Konteksty pisma” w Art. Stations, magazyn szum.pl, 30 marca 2016 r., https:// magazynszum.pl/nieczytelnosc-konteksty-pisma-w-art-stations/ [dostęp: 7.04.2020]. 
Nowa typografia. Podręcznik dla tworzq̨cych w duchu współczesności, „2+3D”, 4 września 2011 r., http://www.2plus3d.pl/artykuly/nowa-typografia-podrecznik-dla-tworzacychw-duchu-wspolczesnosci [dostęp: 1.01.2020].

Reputations: Wolfgang Weingart, „Eye”, 1991 r., http://www.eyemagazine.com/feature/ article/reputations-wolfgang-weingart [dostęp: 1.01.2020].

Słownik języka polskiego PWN, https://sjp.pwn.pl/sjp/typografia;2579026.html [dostęp: 28.12.2019].

Stanisław Dróżdż: Poezja konkretna w przestrzeni miasta, KulturalneIngrediencje, 22 grudnia 2017 r., http://kulturalneingrediencje.blogspot.com/2017/12/stanisaw-drozdz-poezja-konkretna-w.html [dostęp: 15.03.2020].

Tulibacka A., Znaczenia i wpływ podstawowych kolorów na odbiorcę. Szybki przeglqad podstawowych kolorów, grafmag.pl, 21 lipca 2014 r., https://grafmag.pl/artykuly/ znaczenia-i-wplyw-podstawowych-kolorow-na-odbiorce [dostęp: 15.03.2020].

Turbicka A., Szkoła szwajcarska (Swiss Style) i jej wykorzystanie w projektowaniu stron internetowych, 28 kwietnia 2016 r., https://grafmag.pl/artykuly/szkola-szwajcarskaswiss-style-i-jej-wykorzystanie-w-projektowaniu-stron [dostęp: 1.01.2020].

Typograficzny pejzaż Wolfganga Weingarta, „2+3D”, 5 marca 2010 r., https://www.2plus3d. pl/artykuly/typograficzny-pejzaz-wolfganga-weingarta [dostęp: 1.01.2020].

VanderLans R., Graphic Design and the Next Big Thing, „Emigre”, https://www.emigre. com/Essays/Magazine/GraphicDesignandtheNextBigThing [dostęp: 1.01.2020 r.].

Willberg H.P., O czym będziemy mówić?, kultura.onet.pl, 2 czerwca 2005 r., https://kultura. onet.pl/fragmenty-ksiazek/o-czym-bedziemy-mowic/hdm66pn [dostęp: 7.04.2020].

Wprowadzenie do współczesnej typografii, „2+3D”, 28 grudnia 2009 r., http://www.2plus3d. pl/artykuly/wprowadzenie-do-wspolczesnej-typografii [dostęp: 1.01.2020]. 